\title{
LOCAL INDUCTION OF INFLAMMATION AFFECTS BONE FORMATION
}

\author{
M. Croes ${ }^{1}$, M.C. Kruyt ${ }^{1}$, L. Loozen ${ }^{1}$, A.H.M. Kragten ${ }^{1}$, H. Yuan², W.J. Dhert ${ }^{1,3}$, F.C. Öner ${ }^{1}$ and J. Alblas ${ }^{1 *}$ \\ ${ }^{1}$ Department of Orthopaedics, University Medical Centre Utrecht, Heidelberglaan 100, 3584 CX Utrecht, \\ The Netherlands \\ ${ }^{2}$ MERLN Institute for Technology-Inspired Regenerative Medicine, Maastricht University, Universiteitssingel 40, \\ 6229 ER Maastricht, The Netherlands \\ ${ }^{3}$ Faculty of Veterinary Medicine, Utrecht University, Yalelaan 1, 3508 TD Utrecht, The Netherlands
}

\begin{abstract}
To explore the influence of inflammatory processes on bone formation, we applied a new in vivo screening model. Confined biological pockets were first created in rabbits as a response to implanted bone cement discs. These biomembrane pockets were subsequently used to study the effects of inflammatory stimuli on ectopic bone formation within biphasic calcium phosphate (BCP) constructs loaded with TNF- $\alpha$, lipopolysaccharide (LPS) or lipoteichoic acid (LTA), all with or without bone morphogenetic protein (BMP)-2. Analysis of bone formation after 12 weeks demonstrated that the inflammatory mediators were not bone-inductive in combination with the $\mathrm{BCP}$ alone, but inhibited or enhanced BMP-induced bone formation. LPS was associated with a strong inhibition of bone formation by BMP-2, while LTA and TNF- $\alpha$ showed a positive interaction with BMP-2. Since the biomembrane pockets did not interfere with bone formation and prevented the leakage of pro-inflammatory compounds to the surrounding tissue, the biomembrane model can be used for in vivo approaches to study local inflammation in conjunction with new bone formation. Using this model, it was shown that the modulation of the inflammatory response could be beneficial or detrimental to the subsequent bone formation process. The co-delivery of inflammatory factors and bone-related growth factors should be further explored as a strategy to enhance the bone-forming efficacy of bone substitutes.
\end{abstract}

Keywords: osteoimmunology, bone regeneration, inflammation, bone morphogenetic protein, tumour necrosis factor alpha, lipopolysaccharide, lipoteichoic acid, rabbit

\footnotetext{
*Address for correspondence:

Jacqueline Alblas, PhD

Department of Orthopaedics

University Medical Centre Utrecht, Rm G05.228

P.O. Box 85500, Utrecht 3508 GA

The Netherlands
}

Telephone: $+31(0) 887550294$

E-mail: j.alblas@umcutrecht.nl

\section{Introduction}

New strategies are needed to reduce the widespread use of bone transplants for the regeneration and restoration of skeletal defects. Considering the complication rate of 10-40 \% (Arrington et al., 1996; Dimitriou et al., 2011), the limited supply of donor bone (Carragee et al., 2011a) and the significant increase in surgery time associated with bone harvesting (Noshchenko et al., 2014), different approaches are being explored to create bone substitutes which can perform similar or better than autograft bone (Baroli, 2009; Dimitriou et al., 2011). The use of stromal or stem cells (Grayson et al., 2015), growth factors (Gothard et al., 2014) and various biomaterials (Barradas et al., 2011), have shown successful outcomes in animal studies. However, these approaches have not yet reached the clinical practice for widespread use, due to regulatory issues and the difficulty of demonstrating the efficacy of these treatments in clinical studies (Tatara et al., 2016). Currently, the bone morphogenetic proteins (BMPs) are the only osteoinductive alternatives for bone grafting in the treatment of large bone defects (Carreira et al., 2014; Ronga et al., 2013). However, their current dosage and delivery method is associated with serious adverse effects (Carragee et al., 2011b; Epstein, 2013), high costs (Garrison et al., 2010) and unpredictable outcomes (Delawi et al., 2016; Hustedt et al., 2014; Vaccaro et al., 2008).

Modulation of the inflammatory response is a relatively new strategy that is being explored to enhance the proosteogenic effects of bone graft substitutes (Liu et al., 2011; Mountziaris et al., 2011; Spiller et al., 2015). As bone has the unique capacity to fully repair under normal conditions, the process of bone fracture healing has been studied as a model for bone regeneration (Claes et al., 2012). After injury, the initial inflammatory phase is essential for optimal fracture healing to occur, as this triggers a complex interaction between infiltrating immune cells, resident cells and bone progenitor cells (Cho et al., 2002; Gerstenfeld et al., 2003b; Kon et al., 2001; Mountziaris et al., 2011). During this phase, proinflammatory cytokines such as TNF- $\alpha$, IL-1, IL-6 and IL-17 act together with BMPs and other transforming growth factor family members to induce processes leading to repair and restoration (Cho et al., 2002; Claes et al., 2012; Croes et al., 2015; Geusens et al., 2013; Nam et al., 2012; Rundle et al., 2006; Schmidt-Bleek et al., 2015; Yang et al., 2007). Several of these cytokines have stimulatory effects on the osteogenic differentiation of mesenchymal stem cells (MSCs) in vitro (Cho et al., 2010; Glass et al., 2011; Mountziaris et al., 2011; Ono et al., 2016). A balanced expression of these cytokines seems to 
be required for optimal fracture healing, since this process may be impaired in patients with chronic inflammation (Claes et al., 2012; Mountziaris et al., 2011), or patients with a systemic and serious acute inflammation such as polytrauma (Bastian et al., 2011; Keel et al., 2005). In a pathological context, inflammatory processes can also result in excessive new bone formation. Some typical examples include ankylosing spondylitis (Haynes et al., 2012), soft tissue trauma (Kan et al., 2011; Peterson et al., 2014), neurogenic trauma (van Kuijk et al., 2002), fibrodysplasia ossificans progressiva (Ramirez et al., 2014) and osteomyelitis (Rana et al., 2009). In these conditions, the same cytokines are expressed (Haynes et al., 2012; Littlewood-Evans et al., 1997; Peterson et al., 2014; Prabhakara et al., 2011) that are known to be crucial in bone fracture healing and MSC osteogenic differentiation.

In addition to being progenitors for the osteogenic lineage, MSCs exert immunomodulatory functions and express various receptors that are involved in inflammatory processes (Kota et al., 2014; Tomchuck et al., 2008; Wang et al., 2014). These include the toll-like-receptors (TLRs), which are most widely expressed on innate immune cells (O'Neill et al., 2013; Romieu-Mourez et al., 2009; Tomchuck et al., 2008). TLR signalling involves similar cascades of signal transduction and transcription regulation as TNF- $\alpha$ signalling (Yarilina et al., 2008), and both can target downstream regulators of osteogenesis in bone progenitor cells (Cho et al., 2010; Hess et al., 2009; Tomchuck et al., 2008). While several lines of evidence show that TNF- $\alpha$ stimulates the osteoblast differentiation in human MSCs, this effect seems receptor-specific for the TLR agonists (Croes et al., 2015; Fiedler et al., 2013; Hess et al., 2009). Furthermore, in vitro, pro-inflammatory mediators only promote osteoblast differentiation in the presence of an osteoinductive factor like dexamethasone or BMP-2, suggesting that the commitment of bone progenitor cells to the osteogenic lineage enhances their responsiveness to inflammatory signals (Croes et al., 2015; Croes et al., 2016; Tomchuck et al., 2008).

In order to create localised tissue responses, a biological membrane (biomembrane) pocket model was tested. This model may particularly serve as a tool for osteoimmunological research. The biomembrane is formed as a response to a polymethyl methacrylate (PMMA) spacer and provides a confined space for the implantation of biomaterials together with various stimuli (Liu et al., 2013; Pelissier et al., 2004; Viateau et al., 2007). This model shows similarities to the air pouch model, where a subcutaneous cavity is generated by the repeated injection of air. This provides a localised environment for the delivery of inflammatory compounds, and the subsequent tracking of the infiltration of inflammatory cells and their produced soluble factors by harvesting the inflammatory exudate (Akbar et al., 2012; Markel et al., 2012). As additional advantages, the biomembrane model allows for multiple identical compartments to be created within the same animal, while the membrane also provides growth factors and cytokines supporting bone formation (Aho et al., 2013; Christou et al., 2014; Pelissier et al., 2004).

We hypothesise that certain pro-inflammatory signals act in synergy with osteoinductive signals to induce bone formation by promoting osteoblast differentiation. To test this, the pro-inflammatory factors TNF- $\alpha$, lipopolysaccharide (LPS) or lipoteichoic acid (LTA) were either or not combined with BMP-2 on porous biphasic calcium phosphate (BCP) scaffolds and implanted in subcutaneous or intramuscular biomembrane pockets in rabbits. The possible synergy between the proinflammatory signals and BMP-2 was investigated in the subcutaneous location, where bone induction is dependent on exogenous BMP-2 delivery. In the intramuscular environment, however, the $\mathrm{BCP}$ material is bone-inductive without exogenous growth factors (Yuan et al., 2006), allowing us to study the interaction between pro-inflammatory signals and osteoinductive signals. Furthermore, to assess the potential of the biomembrane model for osteoimmunological research, we aimed to investigate if the biomembrane environment affects the bone formation in established osteogenic constructs of ceramics loaded with MSCs or BMP-2.

\section{Materials and Methods}

\section{Study design}

First, an assessment study was performed to verify the potential for ectopic bone formation in the biomembrane pocket model. Established constructs for ectopic bone formation, i.e. porous BCP scaffolds loaded with MSCs or BMP-2, were implanted intramuscularly (im) and subcutaneously $(s c)$ in rats $(n=4)$ and rabbits $(n=4)$, inside and outside the biomembrane pockets. The newly formed bone (bone area \%) in the BCP constructs was the primary outcome after 8 weeks (rats) or 12 weeks (rabbits). Subsequently, the rabbit model $(n=11)$ was used to 1$)$ screen for the potential of inflammatory stimuli to induce bone formation intramuscularly and to 2) screen for the modifying effects of inflammatory stimuli on BMP-induced bone formation subcutaneously. The bone volume (bone area \%) in the BCP constructs was the primary outcome after 12 weeks.

\section{Materials}

Poly methyl methacrylate (PMMA, Simplex P, Stryker, Kalamazoo, MI, USA) discs were produced using custommade silicone moulds. The PMMA discs were sterilised in a $1 \mathrm{M} \mathrm{NaOH}$ solution and extensively washed with PBS. Biphasic calcium phosphate (BCP) blocks were made with dimensions of $3.5 \times 3.5 \times 3 \mathrm{~mm}$ (rats) or $6 \times 6 \times 3 \mathrm{~mm}$ (rabbits). These BCP blocks consisted of $20 \pm 5 \%$ $\beta$-tricalcium phosphate and $80 \pm 5 \%$ hydroxyapatite by weight, and had a total porosity of $75 \pm 5 \%$ (Yuan et al., 2002). The BCP blocks were autoclaved at $121{ }^{\circ} \mathrm{C}$ for $30 \mathrm{~min}$ and dried at $60^{\circ} \mathrm{C}$.

The following inflammatory mediators were tested for their effect on bone formation: human tumour necrosis factor alpha (TNF- $\alpha, 14-8329$, Ebioscience, San Diego, CA, USA), lipopolysaccharide (LPS, E. coli, L5418, Sigma, St. Louis, USA), and lipoteichoic acid (LTA, $S$. aureus, L2515, Sigma). These mediators were tested with or without recombinant human BMP-2 (InductOS, Wyeth/ Pfizer, New York, NY, USA). 


\section{Mesenchymal stem cell isolation and culture}

For syngeneic rat MSC transplantations, one rat was killed using an overdose of $\mathrm{CO}_{2}$. Using a sterile technique, the bone marrow was flushed from the femora. For autologous rabbit MSC transplantation, bone marrow was harvested from each animal under general anaesthesia by aspiration from the iliac crest using an $18 \mathrm{G}$ needle. The mononuclear cell fraction was isolated by Ficoll-paque centrifugation and plated in expansion medium, consisting of $\alpha$-MEM (Invitrogen, Carlsbad, CA, USA) supplemented with 10\% $(\mathrm{v} / \mathrm{v})$ heat-inactivated foetal bovine serum (Cambrex, East Rutherford, NJ, USA), $0.2 \mathrm{mM}$ L-ascorbic acid 2-phosphate (Sigma), and 100 units/mL penicillin/ streptomycin (Invitrogen). The cell cultures were kept in a humidified incubator at $37{ }^{\circ} \mathrm{C}$ and $5 \% \mathrm{CO}_{2}$. The adherent cells were expanded to passage 4 and cryopreserved. The cells were replated and cultured for $2 \mathrm{~d}$ before in vivo implantation.

\section{Construct preparation}

For the preparation of MSC or BMP-2 loaded BCP constructs (assessment study, Table 1), solutions of
$10^{7}$ cells $/ \mathrm{mL}$ or $150 \mu \mathrm{g} / \mathrm{mL}$ BMP-2 in PBS were prepared. Subsequently, $25 \mu \mathrm{L}$ (rats) or $70 \mu \mathrm{L}$ (rabbits) of this solution or PBS alone (controls) was pipetted onto the scaffolds. After $2 \mathrm{~h}$ in a humidified incubator, the constructs were submerged in $\alpha$-MEM medium and stored overnight at $37^{\circ} \mathrm{C}$ and $5 \% \mathrm{CO}_{2}$.

For the comparative study (Table 2), inflammatory stimuli were added to the $\mathrm{BCP}$, alone or in combination with BMP-2, as follows: either $15 \mu \mathrm{L}$ PBS im or $15 \mu \mathrm{L}$ of a $100 \mu \mathrm{g} / \mathrm{mL}$ BMP-2 solution in PBS $s c$ was pipetted onto the scaffolds. Subsequently, $55 \mu \mathrm{L}$ fibrin glue alone (controls, Tissucol $500^{\circledR}$, Baxter, Deerfield, IL, USA) or $55 \mu \mathrm{L}$ fibrin glue containing the proinflammatory mediators was pipetted onto the scaffolds. For this purpose, the mediators were resuspended in $27.5 \mu \mathrm{L}$ of the thrombin component (diluted 1:50 in PBS), mixed with $27.5 \mu \mathrm{L}$ of the fibrinogen component (diluted 1:30 in PBS) and immediately pipetted onto the BCP scaffolds. The constructs were prepared on the day of surgery and stored in a humidified environment at $37{ }^{\circ} \mathrm{C}$ until implantation. To determine the release profile, BCP scaffolds were loaded with LPS in fibrin glue. As a control, LPS was loaded onto the scaffolds in PBS.

Table 1. Conditions implanted both in pre-induced biomembrane pockets and in fresh pockets (assessment study in rats and rabbits).

\begin{tabular}{|c|c|c|c|c|c|}
\hline \multirow[b]{2}{*}{ Group } & \multicolumn{2}{|c|}{ MSCs/BMP-2 } & \multirow[b]{2}{*}{$n$} & \multirow[b]{2}{*}{ PMMA size } & \multirow[b]{2}{*}{ BCP size } \\
\hline & (Dose) & (Conc) & & & \\
\hline \multicolumn{6}{|c|}{$\begin{array}{l}\text { Rat subcutaneous and intramuscular groups } \\
(6 \text { week PMMA +8 week BCP) }\end{array}$} \\
\hline Empty control & - & - & 4 & \multirow{3}{*}{$6 \mathrm{~mm} \varnothing \times 4 \mathrm{~mm}$} & \multirow{3}{*}{$3.5 \times 3.5 \times 3 \mathrm{~mm}$} \\
\hline Syngeneic MSCs & $2.5 \times 10^{5}$ & $10^{7} / \mathrm{mL}$ & 4 & & \\
\hline BMP-2 & $3.75 \mu \mathrm{g}$ & $150 \mu \mathrm{g} / \mathrm{mL}$ & 4 & & \\
\hline \multicolumn{6}{|c|}{$\begin{array}{l}\text { Rabbit subcutaneous and intramuscular groups } \\
(6 \text { week PMMA }+12 \text { week } \mathrm{BCP})\end{array}$} \\
\hline Empty control & - & - & 4 & \multirow{3}{*}{$10 \mathrm{~mm} \varnothing \times 4 \mathrm{~mm}$} & \multirow{3}{*}{$6 \times 6 \times 3 \mathrm{~mm}$} \\
\hline Autologous MSCs & $7 \times 10^{5}$ & $10^{7} / \mathrm{mL}$ & 4 & & \\
\hline BMP-2 & $10.5 \mu \mathrm{g}$ & $150 \mu \mathrm{g} / \mathrm{mL}$ & 4 & & \\
\hline
\end{tabular}

BMP-2: bone morphogenetic protein 2, BCP: biphasic calcium phosphate, MSC: mesenchymal stem cell, PMMA: polymethyl methacrylate.

Table 2. Conditions implanted in pre-induced biomembrane pockets (comparative study in rabbits).

\begin{tabular}{|c|c|c|c|c|c|}
\hline \multirow[b]{2}{*}{ Group } & \multicolumn{2}{|c|}{ BMP-2 } & \multicolumn{2}{|c|}{ Mediator } & \multirow[b]{2}{*}{$n$} \\
\hline & (Dose) & (Conc) & (Dose) & (Conc) & \\
\hline \multicolumn{6}{|c|}{$\begin{array}{l}\text { Rabbit intramuscular groups } \\
(5 \text { week PMMA+12 week BCP) }\end{array}$} \\
\hline Control & \multicolumn{2}{|c|}{$\times$} & \multicolumn{2}{|r|}{$x$} & 11 \\
\hline TNF- $\alpha$ & \multicolumn{2}{|c|}{$x$} & $1,10,100 \mathrm{ng}$ & $14.3,143,1430 \mathrm{ng} / \mathrm{mL}$ & 8 \\
\hline LPS & \multicolumn{2}{|c|}{$x$} & $0.1,1,10 \mu \mathrm{g}$ & $1.4,14.3,143 \mu \mathrm{g} / \mathrm{mL}$ & 8 \\
\hline LTA & \multicolumn{2}{|c|}{$\times$} & $0.5,5,50 \mu \mathrm{g}$ & $7.1,71,710 \mu \mathrm{g} / \mathrm{mL}$ & 8 \\
\hline \multicolumn{6}{|c|}{$\begin{array}{l}\text { Rabbit subcutaneous groups } \\
(5 \text { week PMMA+12 week BCP) }\end{array}$} \\
\hline Control & $1.5 \mu \mathrm{g}$ & $22 \mu \mathrm{g} / \mathrm{mL}$ & \multicolumn{2}{|r|}{$\times$} & 11 \\
\hline TNF- $\alpha$ & $1.5 \mu \mathrm{g}$ & $22 \mu \mathrm{g} / \mathrm{mL}$ & $1,10,100 \mathrm{ng}$ & $14.3,143,1430 \mathrm{ng} / \mathrm{mL}$ & 8 \\
\hline LPS & $1.5 \mu \mathrm{g}$ & $22 \mu \mathrm{g} / \mathrm{mL}$ & $0.1,1,10 \mu \mathrm{g}$ & $1.4,14.3,143 \mu \mathrm{g} / \mathrm{mL}$ & 8 \\
\hline LTA & $1.5 \mu \mathrm{g}$ & $22 \mu \mathrm{g} / \mathrm{mL}$ & $0.5,5,50 \mu \mathrm{g}$ & $7.1,71,710 \mu \mathrm{g} / \mathrm{mL}$ & 8 \\
\hline
\end{tabular}

BMP-2: bone morphogenetic protein 2, BCP: biphasic calcium phosphate, TNF- $\alpha$ : tumour necrosis factor alpha, LPS: lipopolysaccharide, LTA: lipoteichoic acid. 
The constructs were kept in $\mathrm{PBS}$ at $37^{\circ} \mathrm{C}$. At different time points, samples were taken from the PBS to determine the LPS concentration using a Limulus Amoebocyte Lysate assay according to the manufacturer's protocol (Genscript, Piscataway, NJ, USA). It was found that the LPS was better retained using the fibrin glue method during the first hours, although the LPS was completely released from the constructs within $24 \mathrm{~h}$ in both conditions (Fig. 1).

\section{Animals}

Animal experiments were performed after approval of the local Ethics Committee for Animal Experimentation and in compliance with the Institutional Guidelines on the use of laboratory animals (Utrecht University, Utrecht, The Netherlands). A total of fifteen male New Zealand white rabbits (14 weeks old, 2.5-3.0 kg, Crl:KBL, Charles River, L'Arbresle, France) and five male Fischer rats (14 weeks old, 300-350 g, F344/IcoCrl, Charles River) were used for the experiments. Four rabbits and five rats were used to evaluate the ectopic bone formation within the induced biomembrane (assessment study). Eleven rabbits were used to study the effect of inflammatory stimuli on ectopic bone induction and formation (comparative study). All animals were housed at the Central Laboratory Animal Research Facility, Utrecht University. They were allowed to acclimatise for at least two weeks before the surgery. Food and water were given ad libitum.

\section{Surgical procedure}

The animals underwent two surgeries under general anaesthesia as part of the two-step biomembrane pocket model (Fig. 2). In general, the same surgical methods were applied for the assessment and comparative study. As a difference, the two surgeries were separated by a period of six weeks in the assessment study, and five weeks in the comparative study. Rats received $3 \%$ isoflurane, while rabbits received Ketamine $\left(15 \mathrm{mg} / \mathrm{kg}\right.$ im; Narketan ${ }^{\circledR}$, Vétoquinol BV, 's-Hertogenbosch, The Netherlands) and Glycopyrrolate $(0.1 \mathrm{mg} / \mathrm{kg} \mathrm{im}$; Robinul, Riemser Arzneimittel AG, Greifswald, Germany) preoperatively, and Medetomidine $\left(0.25 \mathrm{mg} / \mathrm{kg} s c\right.$; Dexdomitor ${ }^{\circledR}$, Orion Corporation, Espoo, Finland) perioperatively. Anaesthesia was reversed with Atipamezole hydrochloride (0.5$1.0 \mathrm{mg} / \mathrm{kg}$ intravenous, Atipam ${ }^{\circledR}$, Eurovet Animal Health B.V., Bladel, The Netherlands). The rabbits received antibiotic prophylaxis with Enroflaxicine $(10 \mathrm{mg} / \mathrm{kg}$ $s c$; Baytril ${ }^{\circledR}$, Leverkusen, Germany) once daily for $3 \mathrm{~d}$ perioperative during the first surgery, and Penicillin $\left(3 \times 10^{4}\right.$ IE benzylpenicilline $/ \mathrm{kg}$, Duplocilline ${ }^{\circledR}$, Merck Animal Health, Madison, NJ, USA) once during the second surgery. Animals were given pain relief preoperatively, and postoperatively every $8 \mathrm{~h}$ for $2 \mathrm{~d}$ with Buprenorphine (0.03 mg/kg sc; Temgesic ${ }^{\circledR}$, RB Pharmaceuticals Limited, Slough, UK).

After shaving and disinfecting the skin with povidoneiodine (Betadine), a midline incision was made to expose the paraspinal muscles. In the rabbits, four intramuscular pockets were created on each side by blunt dissection for implantation of the PMMA discs (Fig. 2b). The same approach was used for the subcutaneous pockets. In the assessment study, each animal received two additional

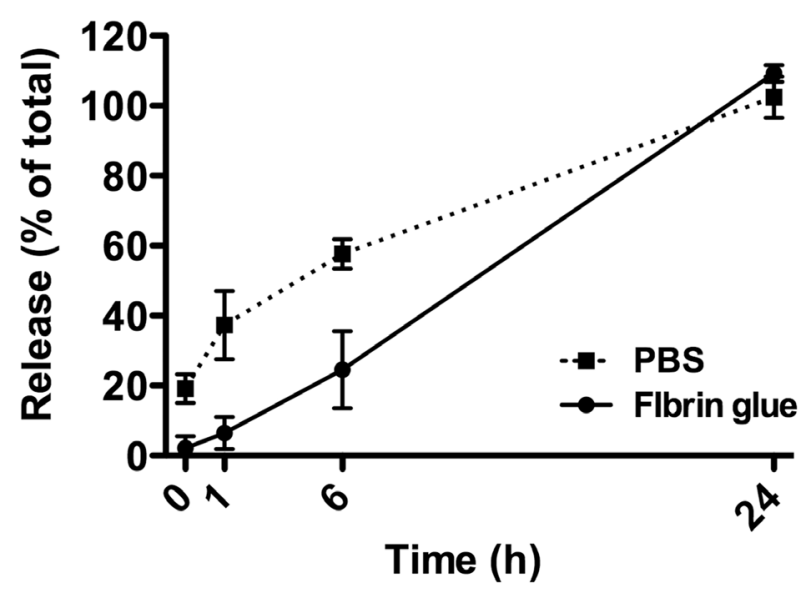

Fig. 1. In vitro release of LPS from the BCP constructs. LPS was loaded in fibrin glue or in PBS, and its concentration was measured in the supernatant at different time points.

subcutaneous PMMA implantations for histological analyses of the biomembrane. Pockets were closed with a non-resorbable suture (Prolene ${ }^{\circledR}$, Ethicon, NJ, USA), followed by closure of the skin (Monocryl ${ }^{\circledR}$, Ethicon). At the second surgery, an incision was made in the membrane surrounding the PMMA disc, the disc was replaced by a $\mathrm{BCP}$ construct, and the opening was sutured $\left(\right.$ Prolene ${ }^{\circledR}$ ). For the assessment study, duplicate constructs were also implanted in freshly prepared intramuscular and subcutaneous pockets during the second surgery. Furthermore, as part of the assessment study, two subcutaneous biomembranes were explanted from each animal during the second surgery and fixed in $4 \%$ formalin for histology.

Fluorochrome labels were injected $s c$ to determine the onset and location of new bone formation (van Gaalen et al., 2010): calcein green at week $4(10 \mathrm{mg} / \mathrm{kg} s c$ in $0.2 \mathrm{M}$ $\mathrm{NaHCO}_{3}$, Sigma $)$, oxytetracycline at week $8(25 \mathrm{mg} / \mathrm{kg}$ $s c$ in 50/50 PBS/demineralised water, Merck Millipore, Billerica, USA) and xylenol orange at week 11 (30 mg/ $\mathrm{kg} s c$ in $0.12 \mathrm{M} \mathrm{NaHCO}_{3}$, Sigma). The incorporation of fluorochromes in the bone was examined by fluorescence microscopy on methyl methacrylate-embedded sections. The rats were killed with $\mathrm{CO}_{2}, 8$ weeks after the second surgery. The rabbits were killed 12 weeks after the second surgery under general anaesthesia, by an intravenous Pentobarbital injection (Euthanimal ${ }^{\circledR}$, Alfasan Nederland BV, Woerden, The Netherlands). In the assessment study, an additional procedure was performed $5 \mathrm{~h}$ prior to termination. In each animal, $100 \mu \mathrm{L}$ of a $175 \mu \mathrm{g} / \mathrm{mL}$ LPS solution was injected through the skin into one of the biomembrane pockets using a 27-gauge needle, while the injection of PBS in another pocket served as a negative control. The presence of phagocytes at the BCP-biomembrane interface was determined by immunohistochemical staining.

\section{Bone histomorphometry}

After retrieval of the constructs, a quarter of each sample was removed for decalcification and paraffin embedding 


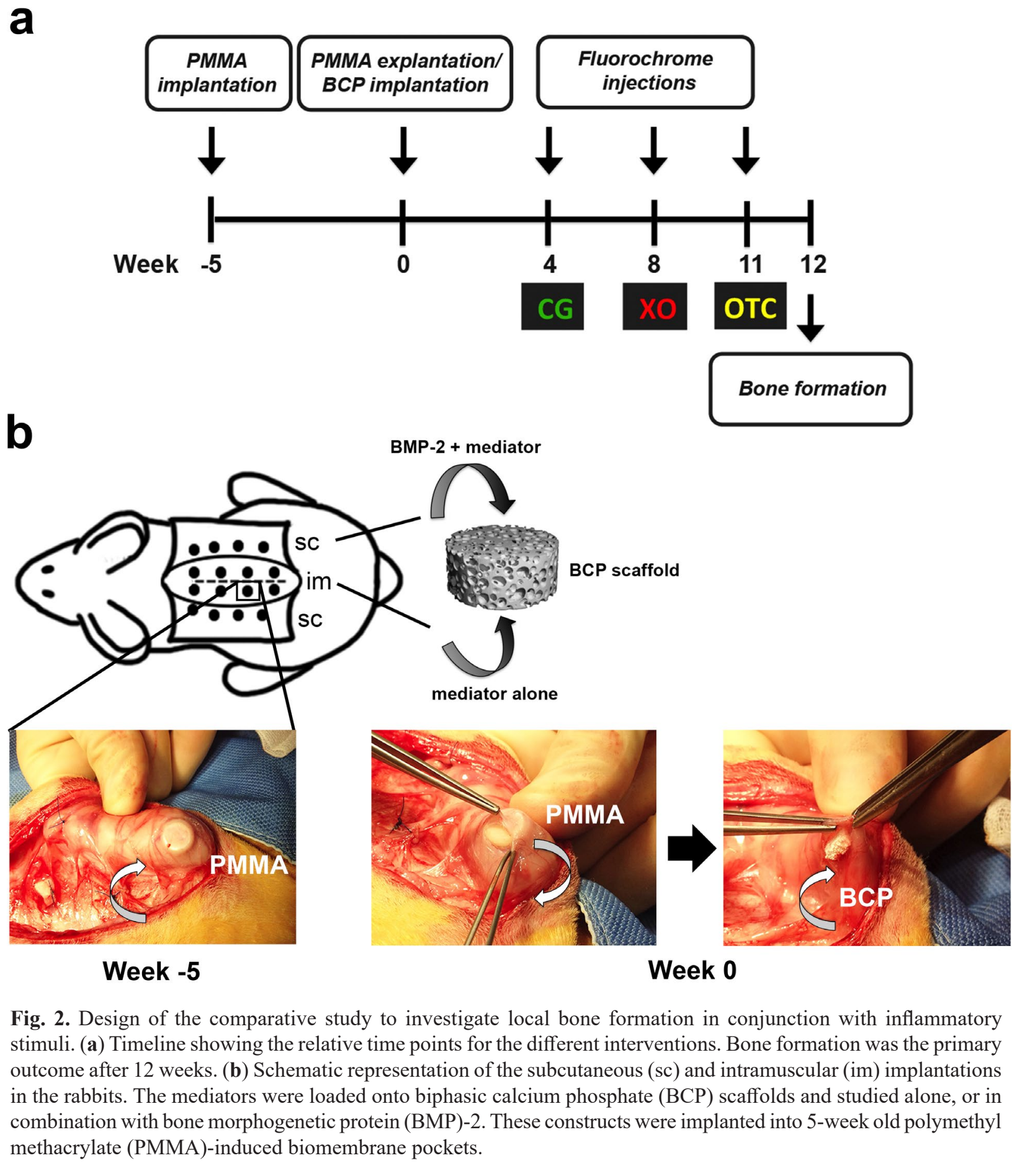

using a rotary tool with circular saw attachment (Dremel 4000, Mount Prospect, IL, USA). The remaining material was fixed in $4 \%$ paraformaldehyde, dehydrated by an ethanol series and embedded in methyl methacrylate (MMA, Merck Millipore). Subsequently, $35 \mu \mathrm{m}$-thick sections were cut using a sawing microtome (Leica, Nusslochh, Germany) and stained with basic fuchsin and methylene blue. The samples were completely sectioned and scored for the presence of bone. Images of two midsections were pseudo-coloured using Adobe Photoshop CS6 (Adobe Systems, San Jose, USA), to quantify the percentage of bone in the available pore space (bone area $\%)$. The mean value of two sections per sample was used for further statistical analyses. For four rabbits, one MMA section per BCP sample was left unstained for fluorochrome detection by fluorescence microscopy (Olympus BX51 with DP70 camera, Olympus, Shinjuku, Tokyo, Japan).

\section{Immunohistochemical stainings}

Sections of decalcified (0.3 M EDTA) BCP samples were embedded in paraffin and cut into $6 \mu \mathrm{m}$ sections. Antigen retrieval was performed with $0.1 \%(\mathrm{w} / \mathrm{v})$ proteinase $\mathrm{K}$ for $15 \mathrm{~min}$ at $37{ }^{\circ} \mathrm{C}$, followed by blocking steps with $0.3 \%$ (v/v) $\mathrm{H}_{2} \mathrm{O}_{2}$ in $\mathrm{PBS}$ for $10 \mathrm{~min}$ and $5 \%$ bovine serum albumin (BSA) for $30 \mathrm{~min}$ at room temperature.

For staining of macrophages and neutrophils, sections were incubated with the mouse-anti-human calprotectin 
antibody $(5 \mu \mathrm{g} / \mathrm{mL}, \mathrm{MCA} 874 \mathrm{~A} 488$, clone MAC387, Hercules, CA, USA) for $2 \mathrm{~h}$ at room temperature. A mouse $\mathrm{IgG}_{1}$ antibody (X0931, Dako) was used as an isotype-matched control. Sections were treated with the secondary antibody (1:200, RPN1001, sheep anti-mouse IgG-Biotin, GE healthcare, Chicago, IL, USA) for $30 \mathrm{~min}$ at room temperature. To enhance the signal, samples were incubated with streptavidin-HRP $(2 \mu \mathrm{g} / \mathrm{mL}, \mathrm{FP} 0397$, Dako $)$ for $30 \mathrm{~min}$. A rabbit spleen was used as a positive control.

For the detection of $\mathrm{T}$ lymphocytes, sections were incubated with a mouse-anti-human CD3 antibody $(0.7 \mathrm{mg} / \mathrm{mL}, \mathrm{M} 7254$, clone F7.2.38, Dako) for $2 \mathrm{~h}$ at room temperature. A mouse $\mathrm{IgG}_{1}$ antibody (X0931, Dako) was used as an isotype-matched control. Sections were incubated with the secondary goat-anti-mouse-HRP $(5 \mu \mathrm{g} / \mathrm{mL}, \mathrm{P} 0447$, Dako) for $30 \mathrm{~min}$ at room temperature. A rabbit lymph node was used as a positive control. Immunostainings were developed with 3,3'-diaminobenzidine tetrahydrochloride hydrate (DAB, D5637, Sigma) and counterstained with Mayer's haematoxylin.

The absolute number of CD3-positive cells in the entire cross-section was quantified. Furthermore, the fraction of $\mathrm{T}$ lymphocytes within the lymphoid clusters was determined by counting the CD3-positive and CD3-negative nuclei within three clusters for three different samples from each group. The number of lymphoid clusters per haematoxylin and eosin (H\&E) stained section was scored by three researchers on blinded samples. A low inter-observer variation in the counts was noted and therefore the average of the counts was used for further analyses.

\section{Statistical analyses}

For the assessment study, an arbitrary sample size of 4 was chosen. All conditions could be implanted in the same animal, thus requiring 4 animals for this study. For the comparative study, a sample size calculation was performed for the bone area $\%$ as main outcome parameter. This showed that a sample size of 8 was needed, based on an estimated effect size of $30 \%$ with a standard deviation of $15 \%$ (Reikeras et al., 2005), using a power of $80 \%$ and an alpha of $1.7 \%$ for multiple pairwise comparisons. Since not all conditions could be implanted in the same animal, 11 rabbits were required for this experiment. All results are shown as the mean \pm standard deviation. Statistics were performed using SPSS version 20.0 (IBM, Chicago, IL,
USA). Differences in bone area \% were analysed using a linear mixed-model approach. One-way ANOVA was used to analyse differences in the average number of lymphoid clusters or CD3-positive cells. Bonferroni correction was used for multiple comparisons. Mixed model regression analysis was used to determine dose response relationships. The significance of intramuscular bone induction was analysed with a linear mixed-model approach with binary outcome measure (i.e. bone or no bone).

\section{Results}

\section{Biomembrane pocket characteristics and influence on bone formation}

A clear biomembrane had formed around the implanted PMMA discs in a period of 6 weeks (Fig. 3a). The biomembrane pockets had similar characteristics in rats and rabbits. They appeared well vascularised by macroscopic evaluation, while microscopically, H\&E staining showed the formation of a 300-400 $\mu \mathrm{m}$ thick membrane. The membranes consisted of a cell-rich inner connective tissue layer with a thickness of 20-50 $\mu \mathrm{m}$. The outer part of the biomembranes consisted of a thicker layer of loose connective tissue, containing larger blood vessels. Histological evaluation showed no signs of inflammation or multinucleated giant cells at the PMMA-biomembrane interface. The biomembrane had appropriate biomechanical properties for handling and suturing, and provided enough space for the implantation of the BCP scaffolds.

To determine if the biomembrane supported the localised delivery of mediators inside of the pocket, a $1 \%$ methylene blue solution was injected into the biomembrane ex vivo. No leakage of the solution out of the membrane was observed (Fig. 3b). Furthermore, the in vivo transcutaneous injection of LPS into the subcutaneous biomembrane on the final day of the experiment resulted in a localised inflammatory response, i.e. presence of phagocytes within the biomembrane pocket but absent outside of the pocket (Fig. 3c). This tissue response was LPS-specific, since no phagocyte infiltrations were observed in the pockets injected with PBS. During the entire study period, the biomembrane-implanted constructs were covered by a thicker fibrous capsule compared to directly-implanted constructs (Fig. 3d).

Fig. 3 (next page). Results of the assessment study to evaluate the ectopic biomembrane pocket model. (a) Histological appearance of the polymethyl methacrylate (PMMA)-induced biomembrane pockets created subcutaneously in rabbits. $H \& E$ staining shows the formation of a thick outer membrane $(\mathrm{O})$ of connective tissue with an endothelium-like inner lining (i) after 6 weeks. Blood vessels were observed in the outer membrane (arrows). (b) Ex vivo injection of methylene blue into the subcutaneous biomembrane pocket in rabbits. (c) Immunohistochemical staining for calprotectin to demonstrate the presence of phagocytes after the injection of LPS (left and middle figure) or PBS (right figure) into the biomembrane. Calprotectin-positive cells (arrows) were observed at the BCP-biomembrane (M) interface, while they were absent in the subcutaneous tissue (sc) outside of the biomembrane pocket. (d) Fibrous capsules observed around directly or biomembrane-implanted BCP constructs in the subcutaneous (sc) and intramuscular (im) locations after 12 weeks in rabbits as shown on methylene blue/basic fuchsin-stained MMA sections. (e,f) Bone formation in the constructs following direct implantation in fresh pockets, or implantation in the pre-induced biomembrane pockets. The pockets were created subcutaneously (sc) and intramuscularly (im) in rats (e) and rabbits (f). Constructs containing BMP-2 $\left(3.75 \mu \mathrm{g}\right.$ in rats, $10.5 \mu \mathrm{g}$ in rabbits) or MSCs $\left(2.5 \times 10^{5}\right.$ in rats, $7 \times 10^{5}$ cells in rabbits $)$ were compared to empty constructs. The results are represented as the mean \pm standard deviation $(n=4)$. 
a

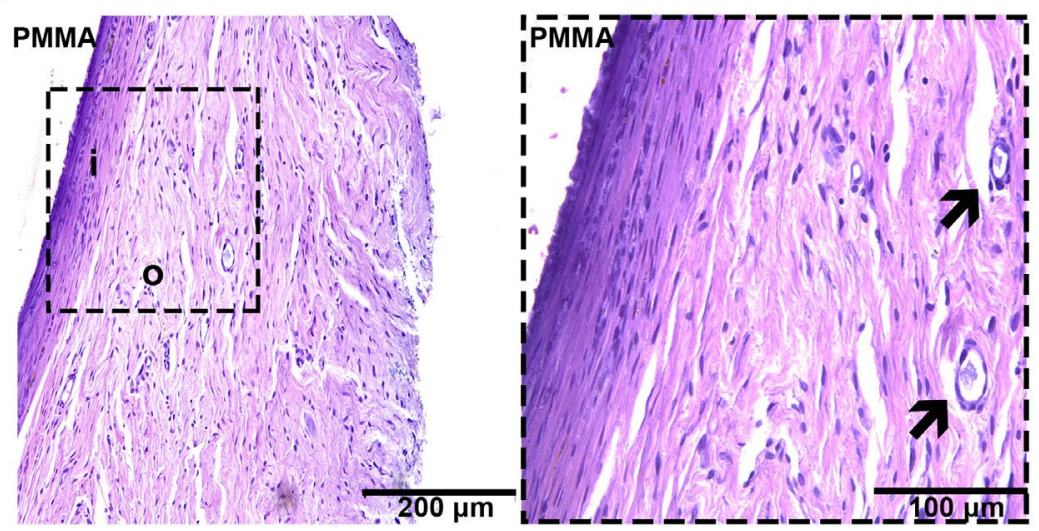

b

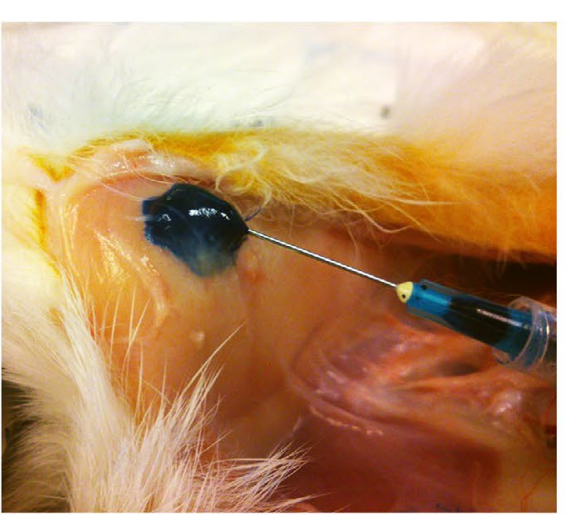

\section{C}
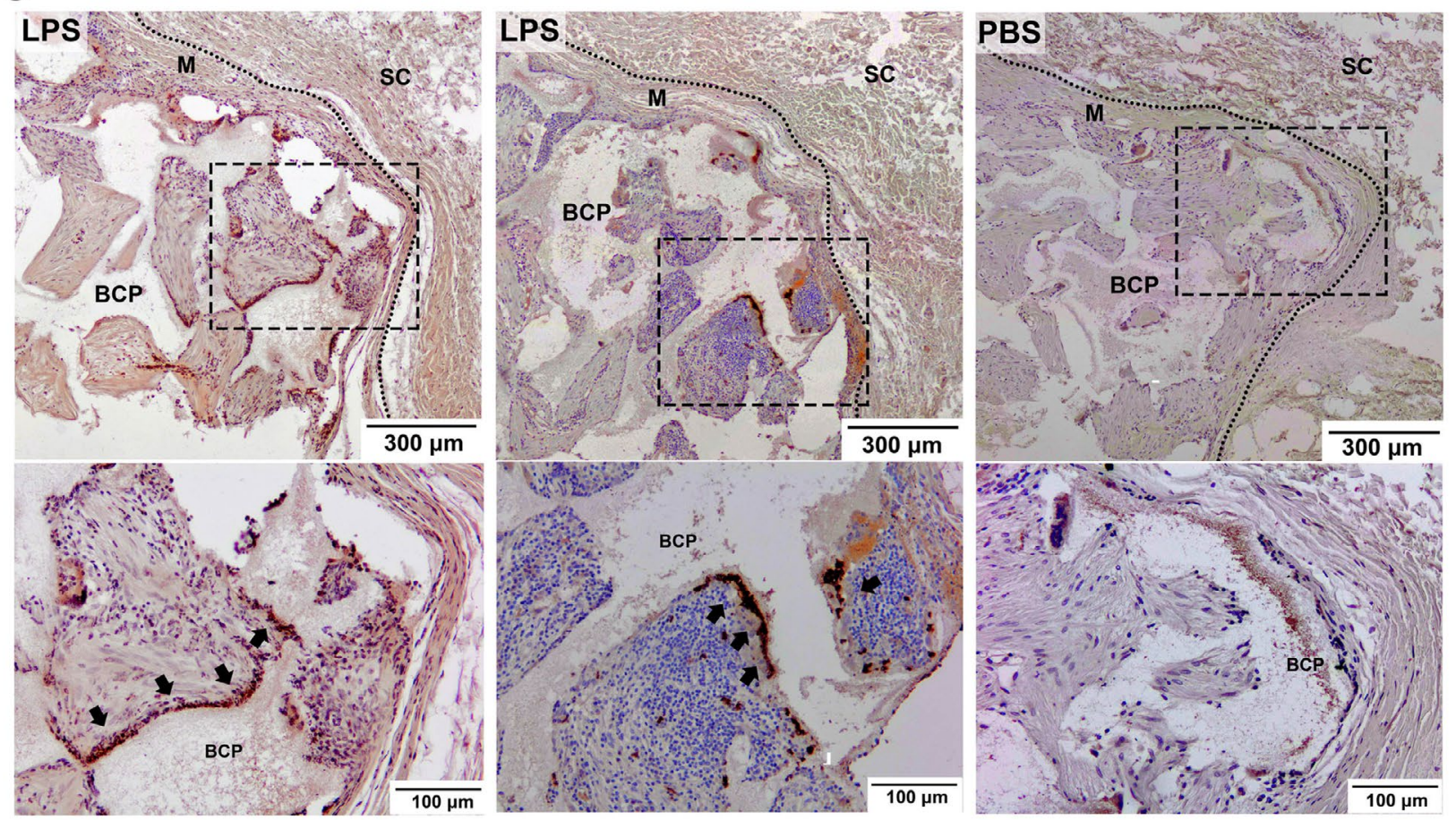
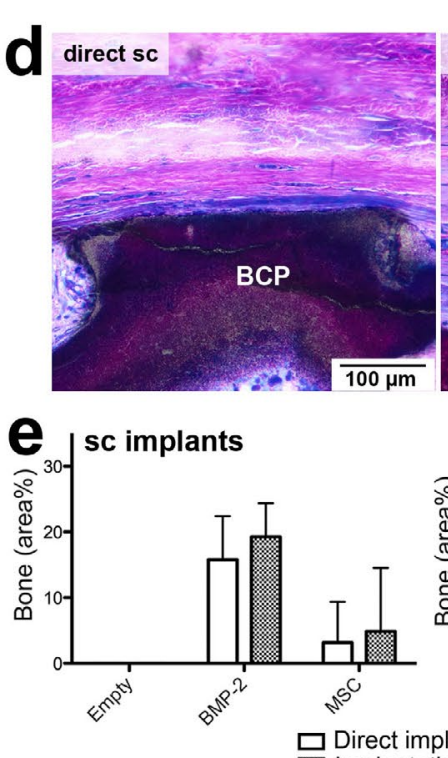

Direct implantation

Implantation in biomembrane
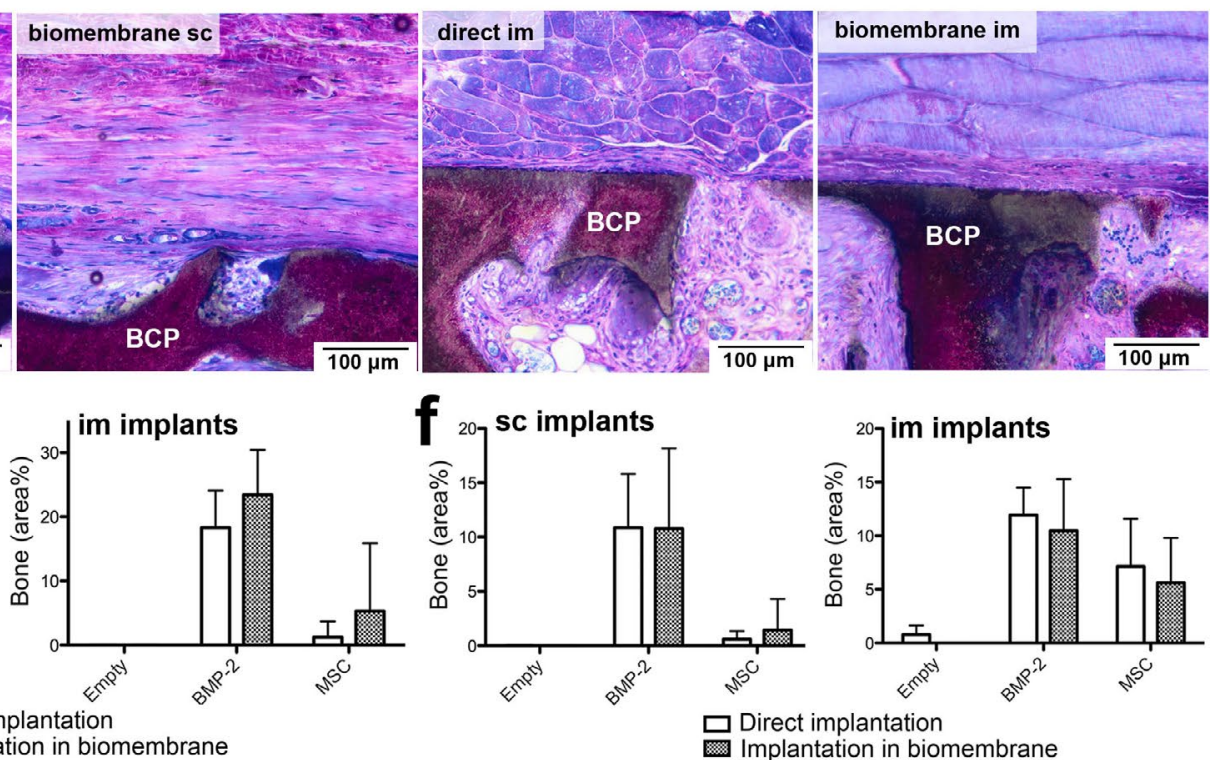

$\square$ Direct implantation

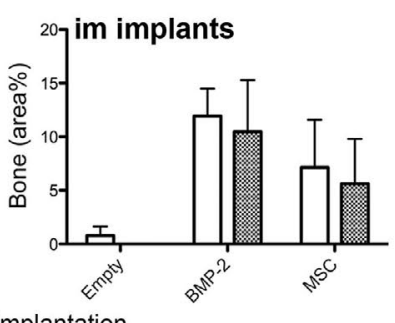

Implantation in biomembrane

Fig. 3 (legend on previous page). 
a

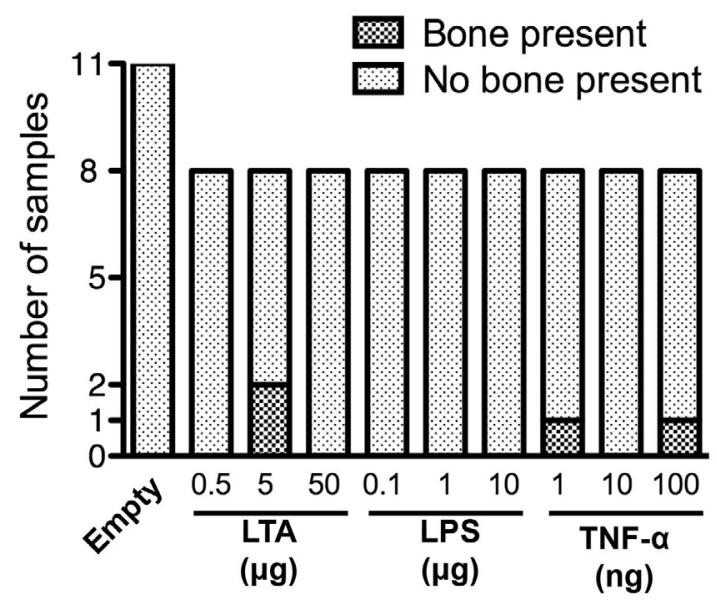

Fig. 4. Bone induction in rabbits in the absence of BMP-2. (a) Scoring for the presence of bone tissue in intramuscularly-implanted empty BCP scaffolds and constructs loaded with pro-inflammatory mediators. (b) Histology of sections stained with methylene blue and basic fuchsin reveals only limited spots of bone (bright pink). B: bone, S: scaffold material. $\mathrm{T}$ : fibrous tissue ingrowth.

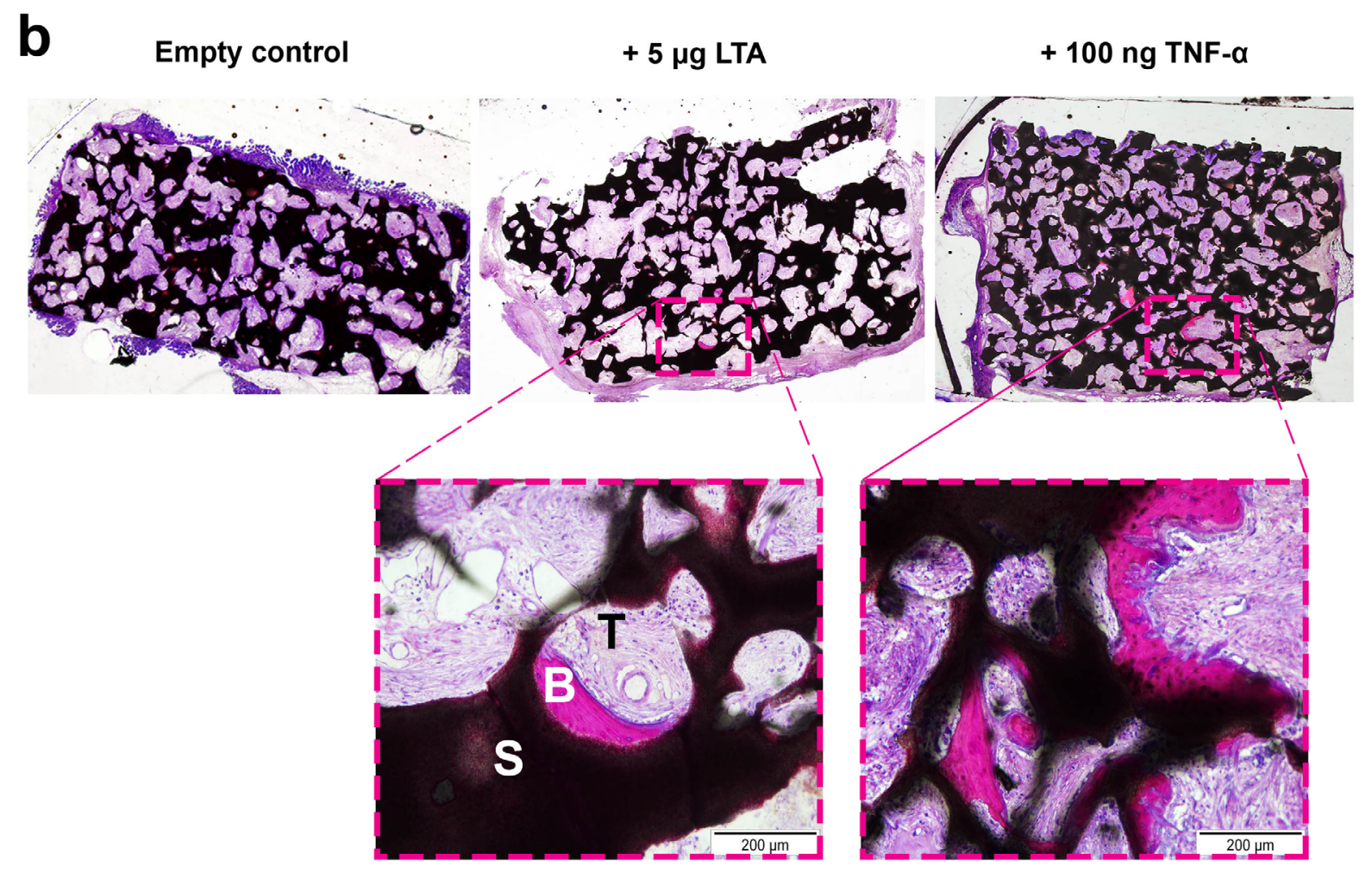

To assess bone formation within the biomembrane, osteogenic constructs were implanted within the induced biomembrane pockets, or in fresh pockets (Table 1). After 8 weeks (rats, Fig. 3e) or 12 weeks (rabbits, Fig. 3f), the bone area $\%$ did not obviously differ for any of the conditions when comparing the biomembrane pockets to the fresh pockets. Whereas empty BCP constructs failed to induce any bone formation ectopically in rats, minute spots of bone were present in 3/4 empty BCP samples in rabbits implanted in the fresh muscle pockets.

\section{Effects of inflammatory stimuli on bone induction}

The intramuscularly-implanted constructs showed no signs of scaffold degradation. Scoring of the empty control scaffolds showed no bone formation after 12 weeks (Fig. 4a). In addition, none of the constructs loaded with LPS demonstrated new bone formation. Although TNF- $\alpha$ induced bone formation in 2 constructs, no concentration dependence was observed. LTA, at the dose of $5 \mu \mathrm{g} / \mathrm{sample}$, was associated with bone formation in $2 / 8$ rabbits. No bone tissue was seen for the other LTA concentrations. The area of this newly formed bone was always less than $1 \%$ and the presence of bone was not significantly associated with one of the conditions (Fig. $4 \mathbf{a}, \mathbf{b}$ ).

\section{Effects of inflammatory stimuli on BMP-2-induced bone formation}

There were no signs of scaffolds degradation seen for the subcutaneously implanted constructs. These constructs, which all contained BMP-2, demonstrated the presence of bone in various amounts in almost all groups. Only the condition loaded with the high dose $(10 \mu \mathrm{g} /$ construct $)$ of LPS did not show any bone. In regions where bone tissue was found, fat tissue was also present in varying amounts. The rest of the BCP pore spaces were filled with fibrous tissue. The rest of the BCP pore spaces were filled with fibrous tissue (Fig. 5a). 
a

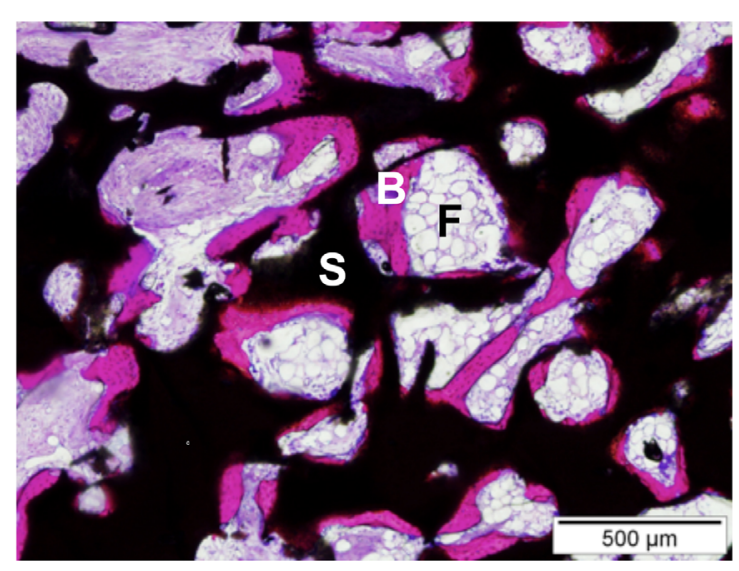

C

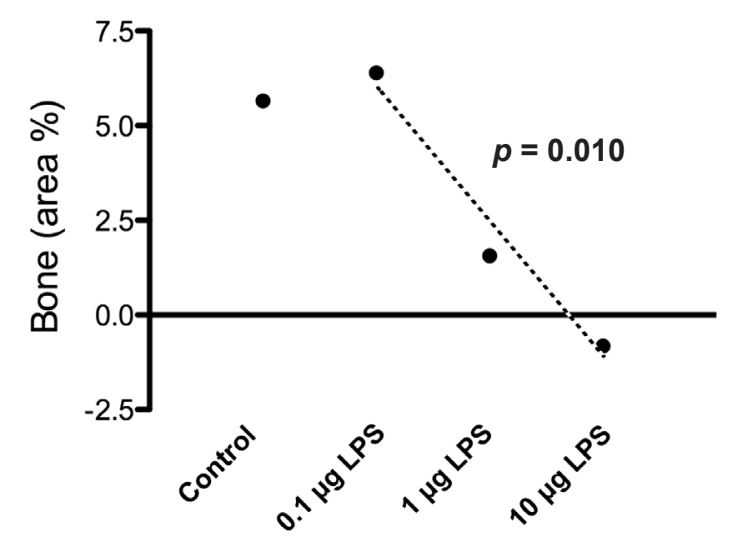

b

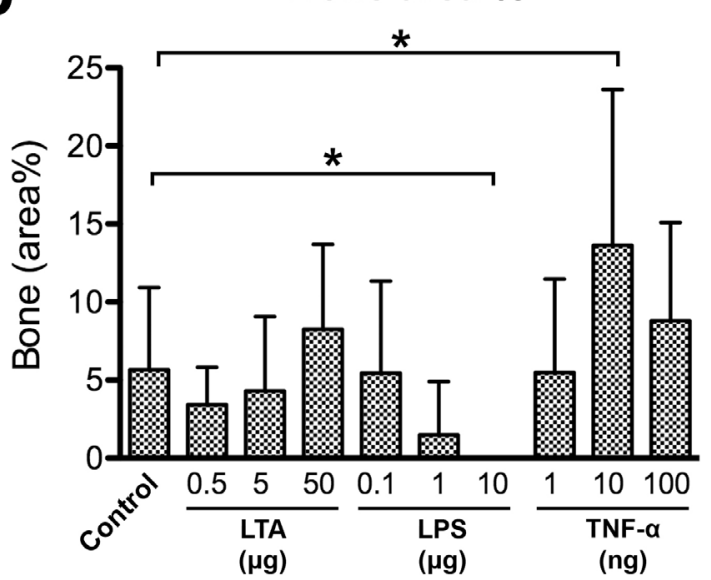

Bone area \%

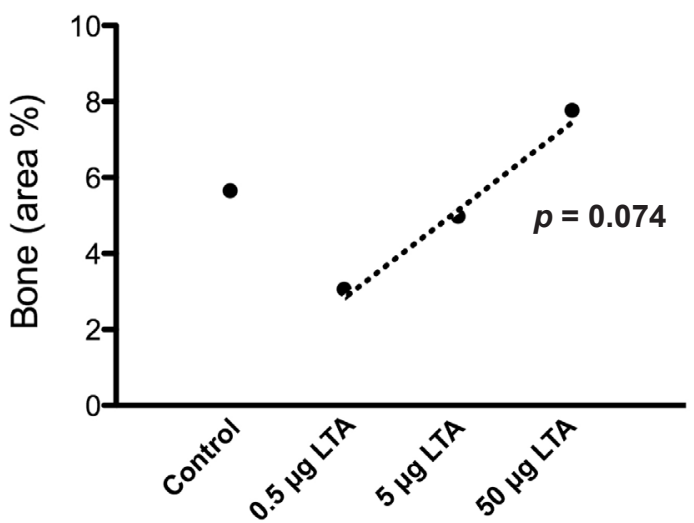

Fig. 5. Bone formation in BMP-2 loaded constructs implanted subcutaneously in rabbits. (a) Histology of methylene blue and basic fuchsin-stained sections, representative for the control samples with 1.5 $\mathrm{g}$ BMP-2 alone. Bone tissue is stained bright pink. B: bone, S: scaffold material. F: fat tissue. (b) Quantification of bone formation in constructs loaded with BMP-2 alone (control) or BMP-2 in combination with pro-inflammatory mediators. The results are represented as the mean \pm standard deviation. $* p<0.05$ compared to the control with $1.5 \mu \mathrm{g}$ BMP-2 alone. (c) Dose-dependent effects of LPS and LTA on new bone formation. Regression analyses shows the linear relationship between the mediator concentration and the amount of bone in subcutaneously implanted constructs. The estimated means are shown together with the trend line.

A relatively low dose of BMP-2 $(1.5 \mu \mathrm{g} /$ construct $)$ was chosen to discriminate the effects of the inflammatory stimuli studied. As a result, there was a large variation in the amount of bone in the samples of the control group $(5.7 \pm 5.3$ area \%, Fig. $5 \mathbf{b})$. In agreement with the histological observations, LPS was associated with a dose-dependent decrease in bone formation. Estimates based on mixed-model regression showed a 3.5-point drop in bone area $\%(p=0.010)$ for each 10 -fold increase in the LPS concentration (Fig. 5c). TNF- $\alpha$, on the other hand, had a stimulatory effect on bone formation that was also concentration-dependent. Constructs containing 10 ng TNF- $\alpha$ were associated with the most prominent bone formation seen in this study. In this group, the bone area $\%$ was doubled $(13.6 \pm 9.9, p=0.005)$ compared to the control $(5.7 \pm 5.3$ area $\%)$. A higher concentration of TNF- $\alpha$ did not result in a further increase in bone formation. Although statistical analysis did not show a difference in the average amount of bone between the control group and the LTA-loaded groups, a borderline linear correlation existed between the LTA concentration and the bone area \% $(p=0.074)$ (Fig. 5c). For the lowest LTA concentration tested, a modest decrease in bone volume was seen, while an increase was found for the highest LTA concentration.

The fluorochrome labels revealed that the dynamics of new bone formation were independent of the bone volume in the different groups (Fig. 6). As such, the constructs co-loaded with $10 \mu \mathrm{g}$ TNF- $\alpha$ and BMP-2 showed the same fluorochrome incorporation as the samples loaded with BMP-2 alone. In all samples associated with bone formation, the 4-week label was located against the border of the BCP, indicating that bone formation had started before week 4 . Furthermore, the 8-week label was present in the different groups throughout the bone indicating that mineralisation continued between week 4 and week 8 . The 11-week label was only seen sporadically, suggesting that there was less active bone mineralisation around this time point. 


\section{Control}
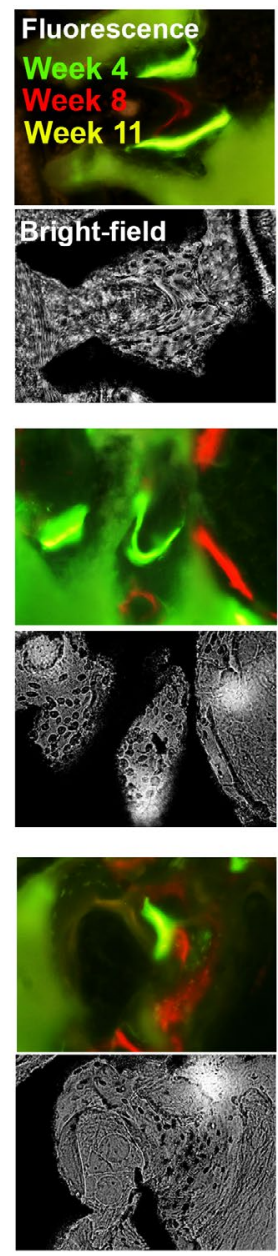
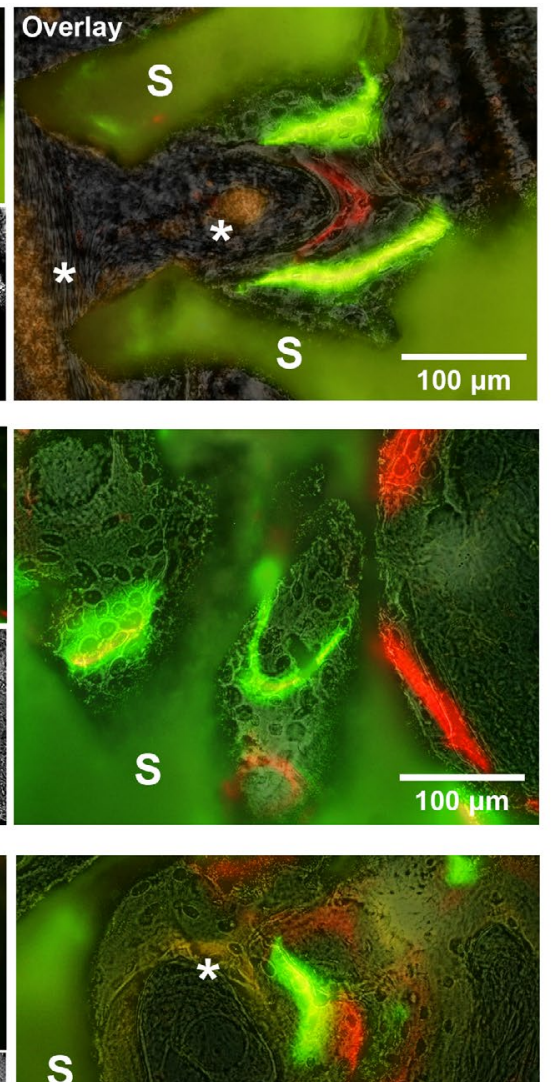

$S$

$100 \mu \mathrm{m}$
+ TNF- $\alpha$
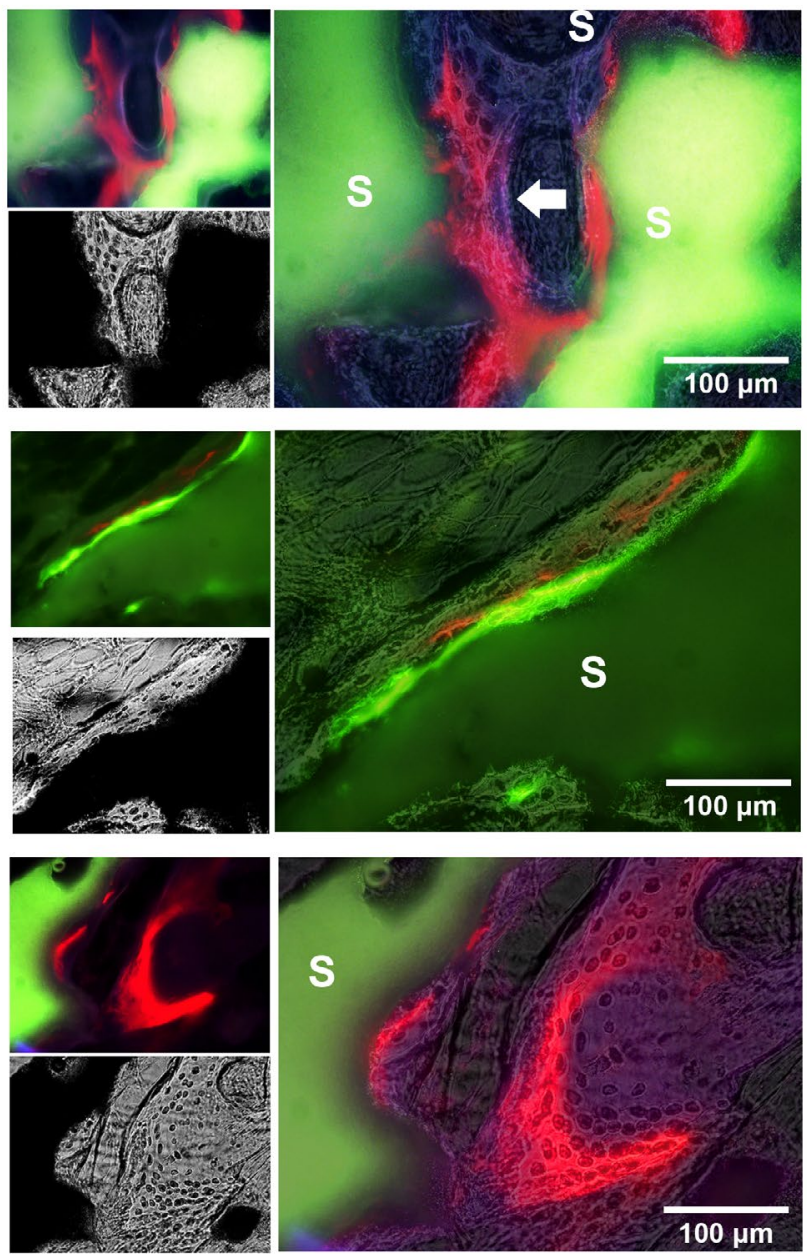

Fig. 6. Fluorochrome incorporation in subcutaneously implanted samples in rabbits. Fluorochromes were injected at 4 (calcein, green), 8 (xylenol orange, red), and 11 (oxytetracycline, yellow) weeks. Their incorporation in new bone was assessed by fluorescence microscopy. Left panel: $1.5 \mu \mathrm{g}$ BMP-2 alone. Right panel: $1.5 \mu \mathrm{g}$ BMP-2 and $10 \mathrm{ng}$ TNF- $\alpha$. The upper, middle and lower panels are representative for three rabbits. Oxytetracycline incorporation (arrow) was only occasionally seen as a thin line, not to be confused with the background as a result of image merging (asterisks). S: scaffold.

\section{Local immune response}

The only immune response present at 12 weeks consisted of dense lymphoid cell clusters (Fig. 7a). After quantifying them in the different groups, it appeared that the constructs loaded with LTA had the lowest average number of lymphoid clusters, while the highest number was found for LPS-loaded constructs (Fig. 7b). Staining for CD3 revealed that a fraction of the cells in the clusters had a $\mathrm{T}$ cell phenotype (Fig. 7a). Quantitative analysis showed that $15-20 \%$ of cells within the clusters were CD3-positive in all groups. Since the BMP-2 loaded samples demonstrated significant differences in bone volume between groups, we determined the number of CD3-positive cells in them (Fig. 7c). No significant differences were found in the absolute number of CD3-positive cells between the inflammatory mediator-loaded constructs and the controls. However, the CD3-positivity correlated with the number of lymphoid clusters in the different conditions. There was no association between the presence of lymphoid cells and the bone volume at the level of individual samples.

\section{Discussion}

Since the modulation of the inflammatory response may be a way to improve the performance of bone substitutes (Gerstenfeld et al., 2003a; Liu et al., 2011; Mountziaris et al., 2011; Reinke et al., 2013; Spiller et al., 2015), there is need for animal models to screen for immunemodifying strategies with stimulatory effects on bone formation. We propose that the creation of biomembrane pockets can serve as a practical tool to investigate the local response to different inflammatory stimuli in conjunction with new bone formation (Liu et al., 2013; Pelissier et al., 2004). Based on the clinical Masquelet technique (Masquelet et al., 2000), the biological membrane is formed as a response to a PMMA spacer. This model has a number of characteristics making it particularly useful for osteoimmunological research. First, the biomembrane can hold synthetic granules or particles of graft material in a confined space (Bosemark et al., 2015; Christou et al., 2014). Furthermore, multiple identical cavities can 
a

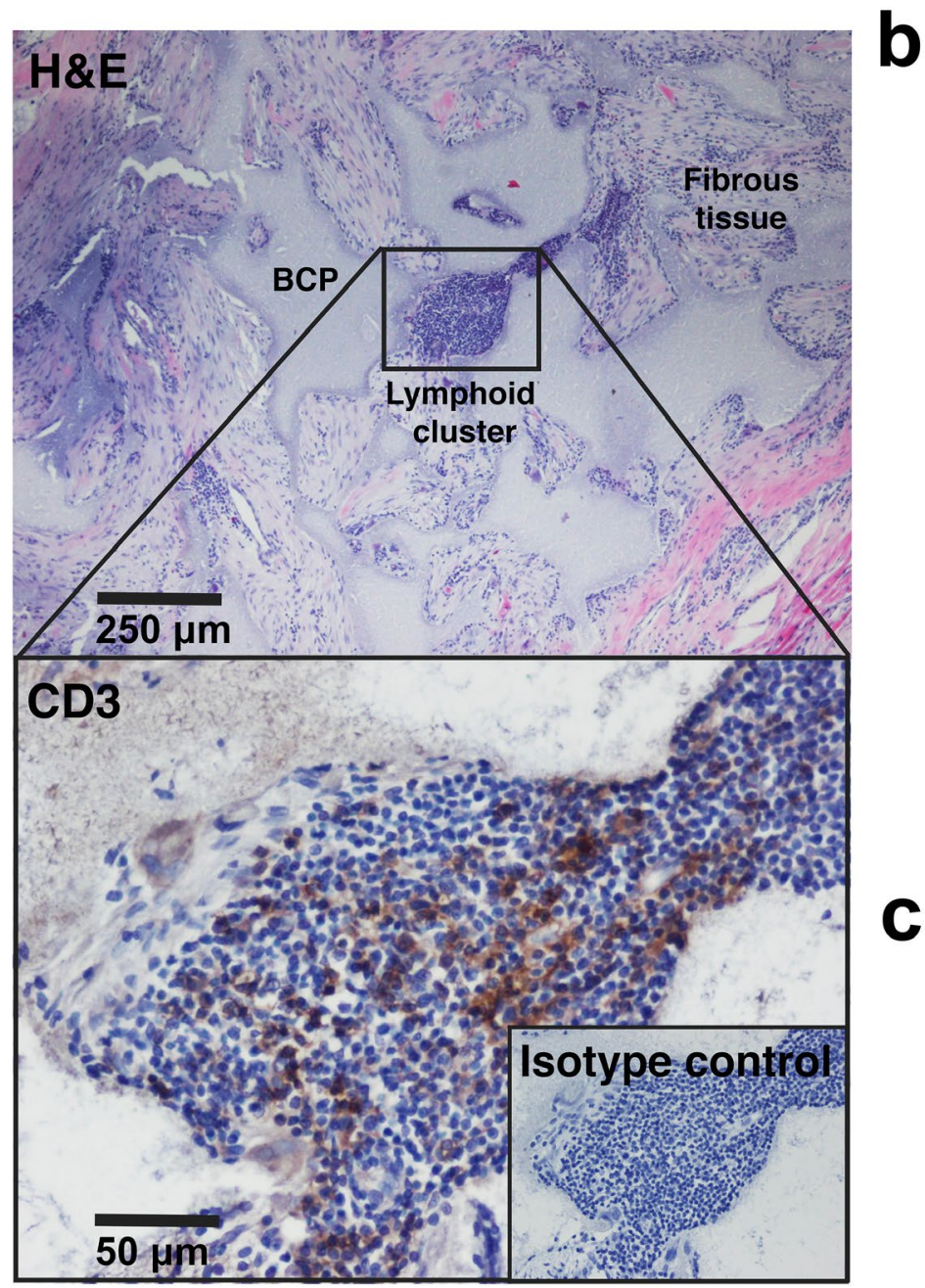

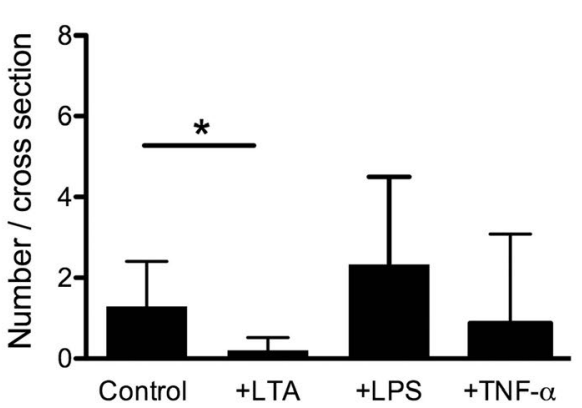
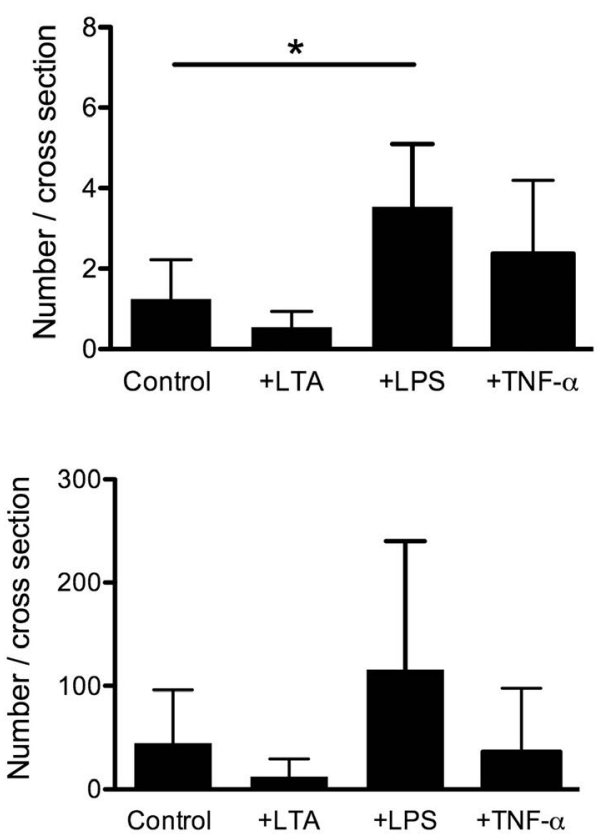

Fig. 7. Presence of lymphoid cell clusters in the constructs after 12 weeks in rabbits. (a) Immunohistochemistry for CD3 shows the presence of T cells within the lymphoid clusters (inset stained with isotype matched control antibody). (b) Quantification of lymphoid clusters in subcutaneous (with BMP-2, upper panel) or intramuscular (without BMP2, lower panel) samples. (c) Quantification of CD3-positive cells in subcutaneous (with BMP-2) samples loaded with $10 \mathrm{ng}$ TNF- $\alpha, 10 \mu \mathrm{g}$ LPS or $50 \mu \mathrm{g}$ LTA. The results are represented as the mean $\pm \operatorname{standard~deviation}(n=8)$. $* p<0.05$ compared to the control group.

be created in the same animal. Moreover, we demonstrate here with local LPS injections that the biomembrane prevents the leakage of immunomodulatory agents to the surrounding tissue. Similar to the air pouch model in rodents (Elliott et al., 2009), the subcutaneous biomembrane pockets in theory allow for the repeated injections of inflammatory compounds, together with the evaluation of the inflammatory exudate. In comparison to the air pouch membrane, the PMMA-induced biomembrane is even 3 to 4-fold thicker (Akbar et al., 2012; Markel et al., 2012; Pelissier et al., 2004). We believe that these practical advantages outweigh the undesired need for a second surgery in this model.

An assessment study was first performed to compare the ectopic bone formation within osteogenic constructs in the biomembrane pocket environment to that of directly implanted constructs (i.e. fresh pockets). Although the group sizes were not chosen to perform powered statistical analyses, we did not observe gross differences in the ectopic bone formation induced by constructs with mesenchymal stem cells or growth factors implanted in a biomembrane pocket relative to directly implanted constructs. Moreover, considering the importance of species-dependency in ectopic bone formation (Yuan et al., 2006), we showed this was true in both rat and rabbit models.

Since the biomembrane environment did not interfere with ectopic bone formation, a comparative study was performed using this model in which distinct inflammatory stimuli were studied for their effect on bone induction and formation. TNF- $\alpha$, LPS and LTA were compared based on their different abilities to affect osteogenic processes in vitro (Croes et al., 2015; Fiedler et al., 2013). It is often postulated that a short inflammatory response is more beneficial for bone healing (Mountziaris et al., 2011; Schmidt-Bleek et al., 2014) or ectopic bone formation (Huang et al., 2014) compared to a sustained response. We therefore studied the inflammatory stimuli using a burst release approach (i.e. released within $24 \mathrm{~h}$ in vitro). Since the mediators significantly affected the bone volume after 12 weeks, it is unlikely that their local action was affected by the surgical procedure. In agreement, measurements performed during more invasive surgical procedures show 
a relatively mild response at the surgical site, with low levels of IL- 6 and IL- 8 in relative to the concentrations of TNF- $\alpha$, LPS and LTA in the BCP constructs (Bastian et al., 2008; Clementsen et al., 2006; Reikeras et al., 2009).

In the current study, the incorporation of a single inflammatory mediator was not an effective strategy to induce a significant amount of new bone formation in the intramuscular location. Although BCP-binding factors or cells induce the formation of matrix-depositing osteoblasts in this location (Yuan et al., 2006), the pro-inflammatory mediators did not further enhance this process. Contrary to this, the same mediators caused profound, but different outcomes when combined with BMP-2. In the optimal condition, the concurrent treatment with TNF- $\alpha$ and BMP-2 resulted in doubling of the bone volume. There have been conflicting reports on the effects of TNF- $\alpha$ on osteogenic differentiation in vitro, i.e. an inhibitive action on rodent MSCs (Gilbert et al., 2002; Lacey et al., 2009) and a stimulatory action on human MSCs (Cho et al., 2010; Croes et al., 2015; Hess et al., 2009). Although there are no other reports of the effects of TNF- $\alpha$ on ectopic bone formation, in an orthotopic model, local TNF- $\alpha$ treatment augmented fracture healing in rats, but only when administered during the first $24 \mathrm{~h}$ after injury (Chan et al., 2015; Glass et al., 2011). In addition to its pro-osteogenic effects (Croes et $a l ., 2015)$, TNF- $\alpha$ may also be involved in cell migration (Glass et al., 2011) or may contribute to angiogenesis (Leibovich et al., 1987; Luo et al., 2006).

Since TLR agonists can affect downstream regulators of osteogenesis in a similar way to TNF- $\alpha$ (Cho et al., 2010; Croes et al., 2015; Fiedler et al., 2013; Hess et al., 2009; Tomchuck et al., 2008; Yarilina et al., 2008), LTA and LPS were also studied for their effect on bone formation. Despite a lacking effect of LTA on MSC osteogenesis in vitro (Fiedler et al., 2013), a correlation was found between the LTA concentration and subsequent bone formation. It should be investigated whether a further increase in LTA concentration results in significant effects. In contrast, although LPS promotes the osteoblast differentiation of human MSCs in the presence of BMP-2 in vitro (Croes et al., 2015; Friedman et al., 2006), it impaired the effects of BMP-2 in a dose-dependent manner in vivo. Considering the important role of TLR receptor signalling in the innate immune response (O’Neill et al., 2013), the direct effects of LPS and LTA on MSC osteogenesis (Croes et al., 2015; Fiedler et al., 2013) were likely overshadowed by the cytokine response to these mediators in vivo. As such, macrophages produce various cytokines in response to TLR agonists (Finney et al., 2012; Kimbrell et al., 2008; $\mathrm{Su}$ et al., 2006). LPS induces an exaggerated secretion of TNF- $\alpha$, IL- 1 and IL- 6 in comparison to LTA or TNF- $\alpha$ (Finney et al., 2012; Kimbrell et al., 2008; Sedger et al., 2014; Su et al., 2006; Yarilina et al., 2008). Of these abovementioned cytokines, TNF- $\alpha$ and IL- 6 contribute to bone healing (Gerstenfeld et al., 2003a; Yang et al., 2007) and enhance the osteogenic differentiation of MSCs (Bastidas-Coral et al., 2016; Glass et al., 2011). Although the conditioned medium derived from LPSstimulated monocytes has been shown to induce osteoblast differentiation of MSCs without exogenous growth factors (Guihard et al., 2012), LPS-stimulated macrophages can also produce IFN- $\gamma$ and NO (Finney et al., 2012; Kimbrell et al., 2008). The synergistic effects of IFN- $\gamma$ and TNF- $\alpha$ may explain the inhibitory effects of LPS on bone induction (Liu et al., 2011; Reinke et al., 2013). NO production after LPS stimulation may also have an inhibitory effect on osteoblast growth and differentiation, partly through a pro-apoptotic effect (Kimbrell et al., 2008; van't Hof et al., 2001). Macrophages may be targeted to the increase the efficacy of bone substitutes. They play an important role in the bone formation by bioceramics, since their blockade inhibits de novo bone formation in bone-inductive $\beta$-tricalcium phosphate (Davison et al., 2014). Moreover, scaffold vascularisation may be improved by inducing a specific macrophage phenotype (Spiller et al., 2015). A better understanding of the involvement of macrophages in the bone-modifying effects of different TLR agonists is therefore highly interesting.

Based on the above, the combination of inflammatory stimuli with bone-related growth factors is expected to be a better approach to physiological bone regeneration when compared to their single delivery. During normal bone fracture healing, bone-promoting growth factors are supported by factors associated with the inflammatory response (Cho et al., 2002; Mountziaris et al., 2011; Rundle et al., 2006). Similarly, we previously observed in vitro that proinflammatory mediators require a second, osteogenic stimulus in order to contribute to osteogenesis (Croes et al., 2015; Croes et al., 2016). This agrees with the current finding that the co-delivery of these factors creates a potent stimulus for new bone formation. The current clinical practice of delivering single supra-physiological doses of BMP-2 could be the reason for its unpredictable induction of new bone formation (Delawi et al., 2016; Hustedt et al., 2014; Vaccaro et al., 2008). Therefore, it is of great interest to elucidate if this co-delivery approach may indeed result in a reduction of the minimal effective BMP dose, considering the high costs (Garrison et al., 2010) and side effects (Carragee et al., 2011b; Epstein, 2013) associated with its current use. Furthermore, it is of importance to investigate if pro-inflammatory stimuli also interact with other BMPs or growth factors associated with bone regeneration (Vo et al., 2012).

As a limitation of this study, we did not investigate the early inflammatory response. However, at the time of explantation, we found a negative correlation between the presence of lymphoid cell clusters and the amount of bone tissue formation caused by BMP-2. In agreement with others (Chatterjea et al., 2014), we show that these cell infiltrations are likely a mixed population of B and T cells. Interestingly, LTA-loaded constructs presented the lowest number of lymphoid cells, while the opposite association was seen for LPS-loaded constructs. T lymphocytes express the TLRs for these antigens and, therefore, can play a direct role in osteogenesis. Alternatively, their activation could also occur secondarily to the innate immune response (MacLeod et al., 2007; Zanin-Zhorov et al., 2007). The local presence of adaptive immune cells can be both stimulatory (Nam et al., 2012; Ono et al., 2016) or inhibitory (Chatterjea et al., 2014; Liu et al., 2011; Reinke et al., 2013) for bone regeneration, and is likely dependent on the contribution of specific T cell subsets. 
For example, IL-17-producing T cells contribute to bone healing and MSC osteogenesis (Croes et al., 2016; Nam et al., 2012; Ono et al., 2016), while other proinflammatory $\mathrm{T}$ cell subsets can also inhibit bone formation (Liu et al., 2011; Reinke et al., 2013). In a follow-up, a functional assay should elucidate whether lymphocytes are actually involved in the bone formation process in this model.

\section{Conclusions}

The ectopic biomembrane pocket model is a suitable in vivo model to study local inflammation in conjunction with new bone formation. The biomembrane environment does not interfere with cell- or growth factor-induced ectopic bone formation, and allows a localised response after the delivery of immunomodulatory agents. In this model, we demonstrated that the local delivery of inflammatory stimuli can either be beneficial or detrimental to the subsequent bone formation process. Pro-inflammatory stimuli by themselves do not induce profound de novo bone formation, but modify the degree of BMP-2-induced bone formation. The appropriate modulation of the early inflammatory response therefore forms an attractive approach to enhance the bone-inductive properties of bone substitutes.

\section{Acknowledgements}

We thank the Anna Foundation for the financial support for the in vivo studies. JA is supported by the Dutch Arthritis Foundation. This study was powered by Health Holland, top sector Life Sciences \& Health. We wish to thank Charlotte van Steen for her help with sawing of the MMA samples.

\section{References}

Aho OM, Lehenkari P, Ristiniemi J, Lehtonen S, Risteli J, Leskela HV (2013) The mechanism of action of induced membranes in bone repair. J Bone Joint Surg Am 95: $597-$ 604.

Akbar M, Fraser AR, Graham GJ, Brewer JM, Grant MH (2012) Acute inflammatory response to cobalt chromium orthopaedic wear debris in a rodent air-pouch model. J R Soc Interface 9: 2109-2119.

Arrington ED, Smith WJ, Chambers HG, Bucknell AL, Davino NA (1996) Complications of iliac crest bone graft harvesting. Clin Orthop Relat Res 329: 300-309.

Baroli B (2009) From natural bone grafts to tissue engineering therapeutics: Brainstorming on pharmaceutical formulative requirements and challenges. J Pharm Sci 98: 1317-1375.

Barradas AM, Yuan H, van Blitterswijk CA, Habibovic P (2011) Osteoinductive biomaterials: current knowledge of properties, experimental models and biological mechanisms. Eur Cell Mater 21: 407-429.

Bastian D, Tamburstuen MV, Lyngstadaas SP, Reikeras O (2008) Systemic and local cytokine kinetics after total hip replacement surgery. Eur Surg Res 41: 334-340.
Bastian O, Pillay J, Alblas J, Leenen L, Koenderman L, Blokhuis T (2011) Systemic inflammation and fracture healing. J Leukoc Biol 89: 669-673.

Bastidas-Coral AP, Bakker AD, Zandieh-Doulabi B, Kleverlaan CJ, Bravenboer N, Forouzanfar T, KleinNulend J (2016) Cytokines TNF-alpha, IL-6, IL-17F, and IL-4 differentially affect osteogenic differentiation of human adipose stem cells. Stem Cells Int 2016: 1318256. doi: 10.1155/2016/1318256.

Bosemark P, Perdikouri C, Pelkonen M, Isaksson $\mathrm{H}$, Tagil M (2015) The masquelet induced membrane technique with BMP and a synthetic scaffold can heal a rat femoral critical size defect. J Orthop Res 33: 488-495.

Carragee EJ, Comer GC, Smith MW (2011a) Local bone graft harvesting and volumes in posterolateral lumbar fusion: a technical report. Spine J 11: 540-544.

Carragee EJ, Hurwitz EL, Weiner BK (2011b) A critical review of recombinant human bone morphogenetic protein-2 trials in spinal surgery: emerging safety concerns and lessons learned. Spine J 11: 471-491.

Carreira AC, Lojudice FH, Halcsik E, Navarro RD, Sogayar MC, Granjeiro JM (2014) Bone morphogenetic proteins: facts, challenges, and future perspectives. J Dent Res 93: 335-345.

Chan JK, Glass GE, Ersek A, Freidin A, Williams GA, Gowers K, Espirito Santo AI, Jeffery R, Otto WR, Poulsom R, Feldmann M, Rankin SM, Horwood NJ, Nanchahal J (2015) Low-dose TNF augments fracture healing in normal and osteoporotic bone by up-regulating the innate immune response. EMBO Mol Med 7: 547-561.

Chatterjea A, LaPointe VL, Alblas J, Chatterjea S, van Blitterswijk CA, de Boer J (2014) Suppression of the immune system as a critical step for bone formation from allogeneic osteoprogenitors implanted in rats. J Cell Mol Med 18: 134-142.

Cho HH, Shin KK, Kim YJ, Song JS, Kim JM, Bae YC, Kim CD, Jung JS (2010) NF-kappaB activation stimulates osteogenic differentiation of mesenchymal stem cells derived from human adipose tissue by increasing TAZ expression. J Cell Physiol 223: 168-177.

Cho TJ, Gerstenfeld LC, Einhorn TA(2002) Differential temporal expression of members of the transforming growth factor beta superfamily during murine fracture healing. J Bone Miner Res 17: 513-520.

Christou C, Oliver RA, Yu Y, Walsh WR (2014) The Masquelet technique for membrane induction and the healing of ovine critical sized segmental defects. PLoS One 9: e114122.

Claes L, Recknagel S, Ignatius A (2012) Fracture healing under healthy and inflammatory conditions. Nature reviews. Rheumatology 8: 133-143.

Clementsen T, Krohn CD, Reikeras O (2006) Systemic and local cytokine patterns during total hip surgery. Scand J Clin Lab Invest 66: 535-542.

Cochran DL (2008) Inflammation and bone loss in periodontal disease. J Periodontol. 79: 1569-1576.

Croes M, Oner FC, Kruyt MC, Blokhuis TJ, Bastian O, Dhert WJ, Alblas J (2015) Proinflammatory mediators enhance the osteogenesis of human mesenchymal stem cells after lineage commitment. PloS one 10: e0132781. 
Croes M, Oner FC, van Neerven D, Sabir E, Kruyt MC, Blokhuis TJ, Dhert WJ, Alblas J (2016) Proinflammatory T cells and IL-17 stimulate osteoblast differentiation. Bone 84: 262-270.

Davison NL, Gamblin AL, Layrolle P, Yuan H, de Bruijn JD, Barrere-de Groot F (2014) Liposomal clodronate inhibition of osteoclastogenesis and osteoinduction by submicrostructured beta-tricalcium phosphate. Biomaterials 35: 5088-5097.

Delawi D, Jacobs W, van Susante JL, Rillardon L, Prestamburgo D, Specchia N, Gay E, Verschoor N, GarciaFernandez C, Guerado E, Quarles van Ufford H, Kruyt MC, Dhert WJ, Oner FC (2016) OP-1 compared with iliac crest autograft in instrumented posterolateral fusion: a randomized, multicenter non-inferiority trial. J Bone Joint Surg Am 98: 441-448.

Dimitriou R, Mataliotakis GI, Angoules AG, Kanakaris NK, Giannoudis PV (2011) Complications following autologous bone graft harvesting from the iliac crest and using the RIA: a systematic review. Injury 42 Suppl 2: S3-15.

Elliott MR, Chekeni FB, Trampont PC, Lazarowski ER, Kadl A, Walk SF, Park D, Woodson RI, Ostankovich M, Sharma P, Lysiak JJ, Harden TK, Leitinger N, Ravichandran KS (2009) Nucleotides released by apoptotic cells act as a find-me signal to promote phagocytic clearance. Nature 461: 282-286.

Epstein NE (2013) Complications due to the use of BMP/INFUSE in spine surgery: the evidence continues to mount. Surg Neurol Int 4: S343-352.

Fiedler T, Salamon A, Adam S, Herzmann N, Taubenheim J, Peters K (2013) Impact of bacteria and bacterial components on osteogenic and adipogenic differentiation of adipose-derived mesenchymal stem cells. Exp Cell Res 319: 2883-2892.

Finney SJ, Leaver SK, Evans TW, Burke-Gaffney A (2012) Differences in lipopolysaccharide- and lipoteichoic acid-induced cytokine/chemokine expression. Intensive Care Med 38: 324-332.

Friedman MS, Long MW, Hankenson KD (2006) Osteogenic differentiation of human mesenchymal stem cells is regulated by bone morphogenetic protein-6. J Cell Biochem 98: 538-554.

Garrison KR, Shemilt I, Donell S, Ryder JJ, Mugford M, Harvey I, Song F, Alt V (2010) Bone morphogenetic protein (BMP) for fracture healing in adults. Cochrane Database Syst Rev 16: CD006950.

Gerstenfeld LC, Cho TJ, Kon T, Aizawa T, Tsay A, Fitch J, Barnes GL, Graves DT, Einhorn TA (2003a) Impaired fracture healing in the absence of TNF-alpha signaling: the role of TNF-alpha in endochondral cartilage resorption. J Bone Miner Res 18: 1584-1592.

Gerstenfeld LC, Cullinane DM, Barnes GL, Graves DT, Einhorn TA (2003b) Fracture healing as a post-natal developmental process: molecular, spatial, and temporal aspects of its regulation. J Cell Biochem 88: 873-884.

Geusens P, Emans PJ, de Jong JJ, van den Bergh J (2013) NSAIDs and fracture healing. Curr Opin Rheumatol 25: 524-531.

Gilbert L, He X, Farmer P, Rubin J, Drissi H, van Wijnen AJ, Lian JB, Stein GS, Nanes MS (2002) Expression of the osteoblast differentiation factor RUNX2 (Cbfa1/AML3/ Pebp2alpha A) is inhibited by tumor necrosis factor-alpha. J Biol Chem 277: 2695-2701.

Glass GE, Chan JK, Freidin A, Feldmann M, Horwood NJ, Nanchahal J (2011) TNF-alpha promotes fracture repair by augmenting the recruitment and differentiation of muscle-derived stromal cells. Proc Natl Acad Sci U S A 108: 1585-1590.

Gothard D, Smith EL, Kanczler JM, Rashidi H, Qutachi O, Henstock J, Rotherham M, El Haj A, Shakesheff KM, Oreffo RO (2014) Tissue engineered bone using select growth factors: A comprehensive review of animal studies and clinical translation studies in man. Eur Cell Mater 28: 166-207.

Grayson WL, Bunnell BA, Martin E, Frazier T, Hung BP, Gimble JM (2015) Stromal cells and stem cells in clinical bone regeneration. Nat Rev Endocrinol 11: 140150 .

Guihard P, Danger Y, Brounais B, David E, Brion R, Delecrin J, Richards CD, Chevalier S, Redini F, Heymann D, Gascan H, Blanchard F (2012) Induction of osteogenesis in mesenchymal stem cells by activated monocytes/ macrophages depends on oncostatin $\mathrm{M}$ signaling. Stem Cells 30: 762-772.

Haynes KR, Pettit AR, Duan R, Tseng HW, Glant TT, Brown MA, Thomas GP (2012) Excessive bone formation in a mouse model of ankylosing spondylitis is associated with decreases in Wnt pathway inhibitors. Arthritis Res Ther 14: R253.

Hess K, Ushmorov A, Fiedler J, Brenner RE, Wirth $\mathrm{T}$ (2009) TNFalpha promotes osteogenic differentiation of human mesenchymal stem cells by triggering the NFkappaB signaling pathway. Bone 45: 367-376.

Huang RL, Yuan Y, Tu J, Zou GM, Li Q (2014) Exaggerated inflammatory environment decreases BMP-2/ACS-induced ectopic bone mass in a rat model: implications for clinical use of BMP-2. Osteoarthritis Cartilage 22: 1186-1196.

Hustedt JW, Blizzard DJ (2014) The controversy surrounding bone morphogenetic proteins in the spine: a review of current research. Yale J Biol Med 87: 549-561.

Kan L, Kessler JA (2011) Animal models of typical heterotopic ossification. J Biomed Biotechnol 2011: 309287. doi: 10.1155/2011/309287.

Keel M, Trentz O (2005) Pathophysiology of polytrauma. Injury 36: 691-709.

Kimbrell MR, Warshakoon H, Cromer JR, Malladi S, Hood JD, Balakrishna R, Scholdberg TA, David SA (2008) Comparison of the immunostimulatory and proinflammatory activities of candidate Gram-positive endotoxins, lipoteichoic acid, peptidoglycan, and lipopeptides, in murine and human cells. Immunol Lett 118: $132-141$.

Kon T, Cho TJ, Aizawa T, Yamazaki M, Nooh N, Graves D, Gerstenfeld LC, Einhorn TA (2001) Expression of osteoprotegerin, receptor activator of NF-kappaB ligand (osteoprotegerin ligand) and related proinflammatory cytokines during fracture healing. J Bone Miner Res 16: 1004-1014.

Konnecke I, Serra A, El Khassawna T, Schlundt C, Schell H, Hauser A, Ellinghaus A, Volk HD, Radbruch 
A, Duda GN, Schmidt-Bleek K (2014) T and B cells participate in bone repair by infiltrating the fracture callus in a two-wave fashion. Bone 64: 155-165.

Kota DJ, DiCarlo B, Hetz RA, Smith P, Cox CS, Jr., Olson SD (2014) Differential MSC activation leads to distinct mononuclear leukocyte binding mechanisms. Sci Rep 4: 4565.

Lacey DC, Simmons PJ, Graves SE, Hamilton JA (2009) Proinflammatory cytokines inhibit osteogenic differentiation from stem cells: implications for bone repair during inflammation. Osteoarthritis Cartilage 17: 735-742.

Leibovich SJ, Polverini PJ, Shepard HM, Wiseman DM, Shively V, Nuseir N (1987) Macrophage-induced angiogenesis is mediated by tumour necrosis factor-alpha. Nature 329: 630-632.

Littlewood-Evans AJ, Hattenberger MR, Luscher C, Pataki A, Zak O, O’Reilly T (1997) Local expression of tumor necrosis factor alpha in an experimental model of acute osteomyelitis in rats. Infect Immun 65: 3438-3443.

Liu H, Hu G, Shang P, Shen Y, Nie P, Peng L, Xu H (2013) Histological characteristics of induced membranes in subcutaneous, intramuscular sites and bone defect. Orthop Traumatol Surg Res 99: 959-964.

Liu Y, Wang L, Kikuiri T, Akiyama K, Chen C, Xu X, Yang R, Chen W, Wang S, Shi S (2011) Mesenchymal stem cell-based tissue regeneration is governed by recipient $\mathrm{T}$ lymphocytes via IFN-gamma and TNF-alpha. Nat Med 17: 1594-1601.

Luo D, Luo Y, He Y, Zhang H, Zhang R, Li X, Dobrucki WL, Sinusas AJ, Sessa WC, Min W (2006) Differential functions of tumor necrosis factor receptor 1 and 2 signaling in ischemia-mediated arteriogenesis and angiogenesis. Am J Pathol 169: 1886-1898.

MacLeod H, Wetzler LM (2007) T cell activation by TLRs: a role for TLRs in the adaptive immune response. Sci STKE 2007: pe48.

Markel DC, Guthrie ST, Wu B, Song Z, Wooley PH (2012) Characterization of the inflammatory response to four commercial bone graft substitutes using a murine biocompatibility model. J Inflamm Res 5: 13-18.

Masquelet AC, Fitoussi F, Begue T, Muller GP (2000) [Reconstruction of the long bones by the induced membrane and spongy autograft]. Ann Chir Plast Esthet 45: 346-353.

Mountziaris PM, Spicer PP, Kasper FK, Mikos AG (2011) Harnessing and modulating inflammation in strategies for bone regeneration. Tissue Eng Part B Rev 17: 393-402.

Nam D, Mau E, Wang Y, Wright D, Silkstone D, Whetstone H, Whyne C, Alman B (2012) T-lymphocytes enable osteoblast maturation via IL-17F during the early phase of fracture repair. PloS one 7: e40044.

Noshchenko A, Hoffecker L, Lindley EM, Burger EL, Cain CM, Patel VV (2014) Perioperative and long-term clinical outcomes for bone morphogenetic protein versus iliac crest bone graft for lumbar fusion in degenerative disk disease: systematic review with meta-analysis. J Spinal Disord Tech 27: 117-135.

O'Neill LA, Golenbock D, Bowie AG (2013) The history of Toll-like receptors - redefining innate immunity. Nat Rev Immunol 13: 453-460.
Ono T, Okamoto K, Nakashima T, Nitta T, Hori S, Iwakura Y, Takayanagi H (2016) IL-17-producing gammadelta $\mathrm{T}$ cells enhance bone regeneration. Nat Commun 7: 10928.

Pelissier P, Masquelet AC, Bareille R, Pelissier SM, Amedee J (2004) Induced membranes secrete growth factors including vascular and osteoinductive factors and could stimulate bone regeneration. J Orthop Res 22: 73-79.

Peterson JR, De La Rosa S, Sun H, Eboda O, Cilwa KE, Donneys A, Morris M, Buchman SR, Cederna PS, Krebsbach PH, Wang SC, Levi B (2014) Burn injury enhances bone formation in heterotopic ossification model. Ann Surg 259: 993-998.

Prabhakara R, Harro JM, Leid JG, Harris M, Shirtliff ME (2011) Murine immune response to a chronic Staphylococcus aureus biofilm infection. Infect Immun 79: 1789-1796.

Ramirez DM, Ramirez MR, Reginato AM, Medici D (2014) Molecular and cellular mechanisms of heterotopic ossification. Histol Histopathol 29: 1281-1285.

Rana RS, Wu JS, Eisenberg RL (2009) Periosteal reaction. AJR Am J Roentgenol 193: W259-272.

Reikeras O, Helle A, Krohn CD, Brox JI (2009) Systemic and local cytokine kinetics in musculoskeletal injury: a prospective study in patients with ankylosing spondylitis. Scand J Clin Lab Invest 69: 198-203.

Reikeras O, Shegarfi H, Wang JE, Utvag SE (2005) Lipopolysaccharide impairs fracture healing: an experimental study in rats. Acta Orthop 76: 749-753.

Reinke S, Geissler S, Taylor WR, Schmidt-Bleek K, Juelke K, Schwachmeyer V, Dahne M, Hartwig T, Akyuz L, Meisel C, Unterwalder N, Singh NB, Reinke P, Haas NP, Volk HD, Duda GN (2013) Terminally differentiated CD8(+) $\mathrm{T}$ cells negatively affect bone regeneration in humans. Sci Transl Med 5: 177ra136.

Romieu-Mourez R, Francois M, Boivin MN, Bouchentouf M, Spaner DE, Galipeau J (2009) Cytokine modulation of TLR expression and activation in mesenchymal stromal cells leads to a proinflammatory phenotype. J Immunol 182: 7963-7973.

Ronga M, Fagetti A, Canton G, Paiusco E, Surace MF, Cherubino P (2013) Clinical applications of growth factors in bone injuries: experience with BMPs. Injury 44 Suppl 1: S34-39.

Rundle CH, Wang H, Yu H, Chadwick RB, Davis EI, Wergedal JE, Lau KH, Mohan S, Ryaby JT, Baylink DJ (2006) Microarray analysis of gene expression during the inflammation and endochondral bone formation stages of rat femur fracture repair. Bone 38: 521-529.

Schmidt-Bleek K, Kwee BJ, Mooney DJ, Duda GN (2015) Boon and bane of inflammation in bone tissue regeneration and its link with angiogenesis. Tissue Eng Part B Rev 21:354-364.

Schmidt-Bleek K, Petersen A, Dienelt A, Schwarz C, Duda GN (2014) Initiation and early control of tissue regeneration - bone healing as a model system for tissue regeneration. Expert Opin Biol Ther 14: 247-259.

Schmidt-Bleek K, Schell H, Schulz N, Hoff P, Perka C, Buttgereit F, Volk HD, Lienau J, Duda GN (2012) Inflammatory phase of bone healing initiates the 
regenerative healing cascade. Cell Tissue Res 347: 567573.

Sedger LM, McDermott MF (2014) TNF and TNFreceptors: From mediators of cell death and inflammation to therapeutic giants - past, present and future. Cytokine Growth Factor Rev 25: 453-472.

Spiller KL, Nassiri S, Witherel CE, Anfang RR, Ng J, Nakazawa KR, Yu T, Vunjak-Novakovic G (2015) Sequential delivery of immunomodulatory cytokines to facilitate the M1-to-M2 transition of macrophages and enhance vascularization of bone scaffolds. Biomaterials 37: 194-207.

Su SC, Hua KF, Lee H, Chao LK, Tan SK, Lee H, Yang SF, Hsu HY (2006) LTA and LPS mediated activation of protein kinases in the regulation of inflammatory cytokines expression in macrophages. Clin Chim Acta 374: 106-115.

Tatara AM, Mikos AG (2016) Tissue engineering in orthopaedics. J Bone Joint Surg Am 98: 1132-1139.

Tomchuck SL, Zwezdaryk KJ, Coffelt SB, Waterman RS, Danka ES, Scandurro AB (2008) Toll-like receptors on human mesenchymal stem cells drive their migration and immunomodulating responses. Stem Cells 26: 99-107.

Vaccaro AR, Lawrence JP, Patel T, Katz LD, Anderson DG, Fischgrund JS, Krop J, Fehlings MG, Wong D (2008) The safety and efficacy of OP-1 (rhBMP-7) as a replacement for iliac crest autograft in posterolateral lumbar arthrodesis: a long-term ( $>4$ years) pivotal study. Spine 33: 2850-2862.

van Gaalen SM, Kruyt MC, Geuze RE, de Bruijn JD, Alblas J, Dhert WJ (2010) Use of fluorochrome labels in in vivo bone tissue engineering research. Tissue Eng Part B Rev 16: 209-217.

van Kuijk AA, Geurts AC, van Kuppevelt HJ (2002) Neurogenic heterotopic ossification in spinal cord injury. Spinal Cord 40: 313-326.

van't Hof RJ, Ralston SH (2001) Nitric oxide and bone. Immunology 103: 255-261.

Viateau V, Guillemin G, Bousson V, Oudina K, Hannouche D, Sedel L, Logeart-Avramoglou D, Petite H (2007) Long-bone critical-size defects treated with tissue-engineered grafts: a study on sheep. J Orthop Res 25: 741-749.

Vo TN, Kasper FK, Mikos AG (2012) Strategies for controlled delivery of growth factors and cells for bone regeneration. Adv Drug Deliv Rev 64: 1292-1309.

Wang Y, Chen X, Cao W, Shi Y (2014) Plasticity of mesenchymal stem cells in immunomodulation: pathological and therapeutic implications. Nat Immunol 15: 1009-1016.

Yang X, Ricciardi BF, Hernandez-Soria A, Shi Y, Pleshko Camacho N, Bostrom MP (2007) Callus mineralization and maturation are delayed during fracture healing in interleukin-6 knockout mice. Bone 41: 928-936.
Yarilina A, Park-Min KH, Antoniv T, Hu X, Ivashkiv LB (2008) TNF activates an IRF1-dependent autocrine loop leading to sustained expression of chemokines and STAT1-dependent type I interferon-response genes. Nat Immunol 9: 378-387.

Yuan H, van Blitterswijk CA, de Groot K, de Bruijn JD (2006) Cross-species comparison of ectopic bone formation in biphasic calcium phosphate (BCP) and hydroxyapatite (HA) scaffolds. Tissue Eng 12: 1607-1615.

Yuan H, Van Den Doel M, Li S, Van Blitterswijk CA, De Groot K, De Bruijn JD (2002) A comparison of the osteoinductive potential of two calcium phosphate ceramics implanted intramuscularly in goats. J Mater Sci Mater Med 13: 1271-1275.

Zanin-Zhorov A, Tal-Lapidot G, Cahalon L, CohenSfady M, Pevsner-Fischer M, Lider O, Cohen IR (2007) Cutting edge: $\mathrm{T}$ cells respond to lipopolysaccharide innately via TLR4 signaling. J Immunol 179: 41-44.

\section{Discussion with Reviewer}

Reviewer: The authors propose a role for activated T-cells in osteoinduction, although in bony locations, activated T-cells are often associated with upregulated RANKL, osteoclastogenesis, and bone resorption - particularly in inflammatory diseases such as periodontitis. Could the authors speculate how upregulated T-cell activation may be a double-edge sword in the clinical setting due to multiple effects on both osteoblast and osteoclast precursors?

Authors: In conditions such as inflammatory arthritis and periodontitis, a high osteoclast activity is the result of continuous presence of $\mathrm{T}$ cells producing RANKL and pro-inflammatory cytokines (Cochran, 2008). Timing is likely important when the chosen strategy is to upregulate $\mathrm{T}$ cell activity for bone formation. In mouse models of bone healing, $\mathrm{T}$ cells infiltrate the damaged site in a very characteristic pattern. Following an initial peak in the presence of $\mathrm{T}$ cells, their numbers drop within a week (Konnecke et al., 2014; Ono et al., 2016). In comparison, a prolonged presence of pro-inflammatory $\mathrm{T}$ cells in the fracture hematoma in sheep is associated with delayed bone healing (Schmidt-Bleek et al., 2012). A bone anabolic therapy targeting $\mathrm{T}$ cells can be controlled in its timing, or could possibly benefit from methods that directly or indirectly suppress the formation of osteoclasts. Moreover, downregulation of $\mathrm{T}$ cell activity with anti-inflammatory drugs may also be a strategy to inhibit their unwanted effects on osteoblasts or osteoclasts (Liu et al., 2011).

Editor's note: The Scientific Editor responsible for this paper was Joost de Bruijn. 